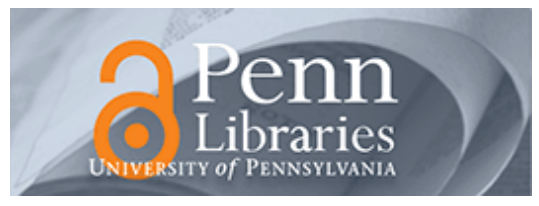

University of Pennsylvania

ScholarlyCommons

Finance Papers

Wharton Faculty Research

2010

The Impact of Foreign Bank Entry in Emerging Markets: Evidence

From India

Todd A. Gormley

University of Pennsylvania

Follow this and additional works at: https://repository.upenn.edu/fnce_papers

Part of the Finance Commons, and the Finance and Financial Management Commons

Recommended Citation

Gormley, T. A. (2010). The Impact of Foreign Bank Entry in Emerging Markets: Evidence From India. Journal of Financial Intermediation, 19 (1), 26-51. http://dx.doi.org/10.1016/j.jfi.2009.01.003

This paper is posted at ScholarlyCommons. https://repository.upenn.edu/fnce_papers/357

For more information, please contact repository@pobox.upenn.edu. 


\title{
The Impact of Foreign Bank Entry in Emerging Markets: Evidence From India
}

\author{
Abstract \\ This paper uses the entry of foreign banks into India during the 1990s-analyzing variation in both the \\ timing of the new foreign banks' entries and in their location-to estimate the effect of foreign bank entry \\ on domestic credit access and firm performance. In contrast to the belief that foreign bank entry should \\ improve credit access for all firms, the estimates indicate that foreign banks financed only a small set of \\ very profitable firms upon entry, and that on average, firms were 8 percentage points less likely to have a \\ loan after a foreign bank entry because of a systematic drop in domestic bank loans. Similar estimates \\ are obtained using the location of pre-existing foreign firms as an instrument for foreign bank locations. \\ Moreover, the observed decline in loans is greater among smaller firms, firms with fewer tangible assets, \\ and firms affiliated with business groups. The drop in credit also appears to adversely affect the \\ performance of smaller firms with greater dependence on external financing. Overall, this evidence is \\ consistent with the exacerbation of information asymmetries upon foreign bank entry. \\ Disciplines \\ Finance | Finance and Financial Management
}




\title{
The Impact of Foreign Bank Entry in Emerging Markets: Evidence from India ${ }^{\dagger}$
}

\author{
Todd A. Gormley ${ }^{*}$
}

This Version: December 10, 2007

\begin{abstract}
This paper uses the entry of foreign banks into India during the 1990s-analyzing variation in both the timing of the new foreign banks' entries and in their locationto estimate the effect of foreign bank entry on domestic credit access and firm performance. In contrast to the belief that foreign bank entry should improve credit access for all firms, the estimates indicate that foreign banks financed only a small set of very profitable firms upon entry, and that on average, firms were eight percentage points less likely to have a loan after a foreign bank entry because of a systematic drop in domestic bank loans. Similar estimates are obtained using the location of preexisting foreign firms as an instrument for foreign bank locations. Moreover, the observed decline in loans is greater among smaller firms, firms with fewer tangible assets, and firms affiliated with business groups. The drop in credit also appears to adversely affect the performance of smaller firms with greater dependence on external financing. Overall, this evidence is consistent with the exacerbation of information asymmetries upon foreign bank entry.
\end{abstract}

Keywords: Foreign Banks, Asymmetric Information, India. JEL Classification: D82, G2, G14, G21, O16.

\footnotetext{
${ }^{\dagger}$ This paper was previously circulated with the title of "Banking Competition in Developing Countries: Does Foreign Bank Entry Improve Credit Access?”

* John M. Olin School of Business, Washington University in St. Louis, Finance Department:, Campus Box \#1133, One Brookings Drive, St. Louis, MO 63130. Telephone: (314) 935-6339, Fax: (314) 935-6359, E-mail: gormley@wustl.edu . I am grateful to Daron Acemoglu, Abhijit Banerjee, Shawn Cole, Bob Cull (discussant), Abhiman Das, Esther Duflo, Michael Faulkender, Radha Gopalan, Simon Johnson, David Matsa, Guy Michaels, Gerard Padro-i-Miquel, Todd Milbourn, Raghuram Rajan, Amit Seru (discussant), Anjan Thakor, Bilal H. Zia and seminar participants at MIT, Olin School of Business -- Washington University, New York Federal Reserve Bank, Federal Reserve Board of Governors, Kelley School of Business -- Indiana University, and Fuqua School of Business -- Duke University for their many useful comments throughout the course of this project. The Prowess data used in this paper was provided by the IMF through their visiting scholars program. The analysis and conclusions in this paper, however, are my own and do not necessarily represent those of the IMF or IMF Policy. All remaining errors and omissions are also my own.
} 
In many less developed countries (LDCs), inefficient domestic banks and a lack of competition among lenders result in high borrowing costs and limited financial access for many firms. More developed countries, such as the U.S., Japan, and those in the European community, argue that LDCs should allow foreign banks to enter into their economies. ${ }^{1}$ By increasing competition, foreign bank entry may increase the supply of credit and improve efficiency. ${ }^{2}$ However, banking theories that incorporate information asymmetries demonstrate that greater competition among banks may actually reduce some firms' access to credit (Petersen and Rajan, 1995). Moreover, the high cost of acquiring information about local firms may limit foreign banks to 'cream-skimming', where they lend only to the most profitable local firms (Dell'Arricia and Marquez, 2004; Sengupta, 2007) and adversely affect both domestic banks and the firms that rely upon them (Gormley, 2007).

These competing theories naturally lead to this paper's central questions: does foreign bank entry improve credit access for domestic firms, and if so, which firms? Moreover, do these changes in the credit market affect the performance of domestic firms? The growing trend among LDCs to allow greater foreign bank entry and the degree of entry that typically occurs suggests that the answers may have important implications for financial policy in these economies. To answer these questions, this paper uses the entry of foreign banks into India during the 1990s to estimate the effect of foreign bank entry on domestic credit access. Geographical variation in foreign bank locations across India over time and the availability of firm-level loan data facilitates the use of novel identification techniques and makes India an ideal setting to analyze the impact of foreign bank entry. Using this data, I find evidence both of 'cream-skimming' by foreign banks and of a systematic drop in loans from domestic banks following foreign bank entry that lowers overall credit access for many domestic firms, particularly smaller firms, firms with fewer tangible assets, and firms affiliated with business

\footnotetext{
${ }^{1}$ In a memo to the World Trade Organization on June 6, 2005, delegations from Japan, the U.S., and E.U. argued that "Policies that impede competition, such as entry restrictions and restrictions on foreign banks, have been shown to raise the cost of financial services and hurt economic performance." WTO Document \#05-2335.

${ }^{2}$ Characteristics unique to foreign banks may also directly increase credit access in LDCs. Foreign banks may be less susceptible to politically-connected loans (Agénor, 2003); domestic banks may benefit directly by adopting the technologies of foreign banks (Lensink and Hermes, 2004); and foreign banks may be more efficient, have access to international capital markets, and encourage the development of better auditing agencies (Levine, 1996).
} 
groups. The drop in credit also appears to adversely affect the performance of smaller firms with greater dependence on external financing. This evidence is consistent with banking theories that incorporate information asymmetries and has numerous policy implications.

To identify the effect of foreign bank entry, I match financial data for Indian firms with the geographical location of newly-established foreign bank branches following India's 1994 commitment to the World Trade Organization (WTO) to allow greater foreign bank entry. Foreign bank entry was staggered: some districts received a foreign bank branch as early as 1994, while others did not receive such a branch until 2001, and as of today, many districts have yet to receive a foreign bank. I then compare changes in the borrowing patterns of domestic firms located geographically near the new banks to changes in the borrowing patterns of firms located further from the new banks. This use of variation both in the timing of the new foreign banks' entries and in their location within the country eliminates potential biases that might arise from other country-wide shifts in economic policy or banking sector regulation. Such country-wide policies would affect all firms in India equally and therefore unlikely explain changes in borrowing trends over time for firms located geographically near foreign banks versus those that are not. Moreover, by using firm-level data, I can also test for changes in credit access across different types of firms as well as control for any differences in the types of firms located in areas with a new foreign bank.

To account for the endogenously-determined location choice of the new foreign banks within India, I also use the geographical distribution of foreign firms in India before the W'TO agreement as an instrument for the location choice of new foreign banks following the agreement. I assume that foreign banks chose to enter markets with firms from their home country in order to preserve preexisting relationships with these firms, but that these foreign firms' presence is not otherwise related to domestic lending trends at the local level. This tendency for foreign banks to follow their customers abroad has been noted in a number of countries (Sabi, 1988; Brealey and Kaplanis, 1996) and seems to occur in India as well. Moreover, there is no evidence that a foreign firm's presence in India was otherwise related to the lending patterns of domestic firms located geographically nearby. 
Further buttressing the empirical design employed in this paper is the fact that numerous tests indicate that the necessary identification assumptions hold, and the instrumental variable (IV) estimates are similar in sign and magnitude to the ordinary least squares (OLS) estimates.

Overall, the estimates suggest that competition from foreign banks is associated with a reallocation of loans that is not necessarily a boon to the lion's share of domestic firms. The most profitable ten percent of firms located near a new foreign bank branch received larger loans, but on average, firms were 7.6 percentage points less likely to have a long-term loan of any size following the entry of a foreign bank. This limited increase in loan sizes appears to arise from new foreign bank loans targeted primarily towards the most profitable firms. The decline in credit for all other firms, however, originates from a systematic drop in domestic bank loans that appears to be supply-driven decline rather than demand-driven. Moreover, this reallocation of loans occurs only for firms located in the vicinity of a new foreign bank, suggesting that banking markets are localized — and there is no evidence to indicate that the borrowing relationships of these firms followed different trends from those of firms located elsewhere in India prior to the entry of a foreign bank. The observed reallocation occurs within 1-2 years of the entry of the foreign bank within each unique district of India and appears to persist for the duration of the sample time period.

The reduction in overall bank credit also appears to disproportionately affect some firms' access to credit and their subsequent performance. The observed decline in loans is greater among smaller firms, firms with fewer tangible assets, and firms affiliated with large business groups. Moreover, smaller firms located in industries requiring greater external financing exhibit a drop in sales growth, profitability, cash reserves, and capital expenditures following foreign entry. These declines in performance indicate an inability to substitute into alternative forms of financing after the drop in credit from domestic banks. Additionally, the larger decrease in domestic loans allocated to firms with fewer tangible assets after foreign bank entry indicates domestic lenders may rely more heavily on fully collateralized loans after foreign bank entry.

This evidence provides support to a recent and growing theoretical literature regarding the 
unique implications of competition between lenders that differ in both their access to information about firms and their respective costs of capital. The targeted lending of foreign banks in India and the subsequent decline of domestic bank loans to informationally opaque firms, as captured by a firms' size and group affiliation, is consistent with foreign lenders 'cream-skimming' the best firms and domestic lenders responding adversely to their entry. These findings also parallel an existing literature that examines the comparative disadvantage of large banks in the production and use of 'soft' information (Berger, Miller, Petersen, Rajan, and Stein, 2005), and the unanticipated consequences that greater competition may have on the lending relationships that small and mediumsized entrepreneurs rely on (Boot and Thakor, 2000; Petersen and Rajan, 1995).

These findings have numerous implications for financial policy in LDCs, which in recent years has increasingly trended towards the allowance of greater foreign bank entry. While the potential benefits of foreign bank entry are many, particularly when domestic banks are primarily state-owned (as in India), the evidence suggests that information asymmetries may prevent many firms in these economies from realizing these benefits. ${ }^{3}$ This evidence suggests that it may be necessary to adopt additional policies—beyond allowing foreign banks entry—to increase efficiency and improve credit access in LDCs. For example, reducing information barriers endemic to LDC credit markets may increase the range of firms that foreign banks are willing to finance upon entry and reduce the likelihood that informationally-opaque firms will be adversely affected by their entry. The evidence also suggests that the sequencing of reforms and fostering of a well-developed domestic financial market prior to foreign bank entry may be important as well.

This paper is related to a number of recent studies on the impact of financial liberalization in emerging economies. The focus on a specific type of liberalization, foreign bank entry, is similar to recent work on the impact of foreign participation in domestic equity markets (Bekaert and Harvey, 2000; Bekaert, Harvey, and Lundblad, 2005; Chari and Henry, 2004; Henry, 2000a and 2000b). This

\footnotetext{
3 The large degree of state-owned banking assets in India (about 80 percent) is quite common among developing countries. See Barth, Caprio, and Levine (2001) for more details.
} 
paper also builds upon existing empirical work that makes use of firm-level and within-country variation to identify the impact of greater bank competition and banking deregulation (Cetorelli and Strahan, 2006; Zarutskie, 2006; and Bertrand, Schoar, and Thesmar, 2007).

Finally, this paper is related to a growing empirical literature that studies the type of domestic firm targeted by foreign banks and the impact of foreign bank entry on domestic bank performance, interest rates, and firms' debt usage and sales. ${ }^{4}$ This paper compliments this literature by analyzing the dynamic implications of foreign bank entry on firms' lending relationships with domestic banks and their subsequent performance and uses within-country variation to mitigate the concern of endogeneity bias that is present in country-level studies. This paper also provides novel evidence regarding the impact of liberalization when foreign bank entry occurs through de novo branches rather than the large scale acquisitions. Recent theoretical work suggests foreign bank entry via de novo branching is more likely to have adverse effects than entry via acquisitions (Gormley, 2007).

The remainder of the paper proceeds as follows. Section I provides a review of India's policy change regarding foreign banks, and Section II describes the data. The baseline regression and identification strategy are explained in Section III, and Section IV reports the OLS estimates. Section V contains robustness checks and IV estimates. Section VI analyzes the differential effect of entry on firms along with other potential effects on firm performance. Finally, Section VII concludes.

\section{Description of Policy Change}

Prior to 1991, India's economy and financial system was heavily regulated and dominated by the public sector. A complicated regulatory regime required firms to obtain licenses for most economic activities, and many industries were reserved for the public sector, including much of the

\footnotetext{
${ }^{4}$ Claessens, Demirguc-Kunt, and Huizinga (2001) uncover evidence that foreign bank entry is associated with lower profit margins among domestic banks, while Berger, Klapper, and Udell (2001), Haber and Musacchio (2004), and Mian (2006) provide evidence that foreign banks tend to finance only larger, more established firms. Clarke, Cull, and Peria (2006) find that entrepreneurs in countries with high levels of foreign bank ownership perceive interest rates and access to loans as smaller constraints to their operations, while Detragiache, Gupta, and Tressal (2007) instead finds that foreign ownership is negatively related to aggregate measures of banking sector performance. Within Eastern European countries, Giannetti and Ongena (2007) find the share of foreign lending to be positively related to firm-level sales and overall debt usage, particularly for larger firms.
} 
financial system. Bank nationalizations in 1969 and 1980 increased the public sector share of deposits to over $80 \%$, and further branch licensing was rigidly controlled. Primarily focused on financing government deficits and serving government priority sectors such as agriculture, India's public banks lacked proper lending incentives and exhibited a high number of non-performing loans. ${ }^{5}$

Following a balance of payments crisis in 1991, however, a number of structural reforms were implemented that greatly deregulated many economic activities, and in November 1991, a broad financial reform agenda was established in India by the Committee on the Financial System (CFS). The CFS was appointed by the Government of India to examine the existing financial system and make recommendations for improving its efficiency so as to more effectively meet the credit needs of firms. One of the committee's recommendations to meet this goal was to introduce greater competition into the banking system by allowing more foreign banks to enter India. It was argued that the entry of additional foreign banks would improve the competitive efficiency of the Indian banking system and induce an upgrading of banking technology.

However, no significant action was taken by the Government of India regarding the CFS recommendation on foreign banks until April 1994 when the government agreed to allow for an expansion of foreign banks under the WTO General Agreement on Trades in Services (GATS). In the initial GATS agreement, India committed to issue five additional branch licenses to both new and existing foreign banks each year. In a subsequent supplemental agreement in July 1995, India increased the limit to eight licenses per year, and in February 1998, the limit was increased to 12. While there were no restrictions on where foreign banks could choose to establish new branches, the expansion of foreign banks in India was by de novo branches only, as foreign banks were not allowed to own controlling stakes in domestic banks. 6

\footnotetext{
${ }^{5}$ See Ghemawat and Khanna (1998), Hanson (2003), and Tarapore (1999) for more details about India's licensing regime and financial system before 1991.

${ }^{6}$ Foreign banks wishing to expand needed to seek RBI approval, as do all banks under Section 23 of the Banking Regulation Act, 1949. Requests for new branches are evaluated on the "merits of each case and taking into consideration overall financial position of the bank, quality of its management, efficacy of the internal control system, profitability, and other relevant factors". See "Master Circular on Branch Licensing," DBOD.No. BL.BC. 5/22.01.001/2004, Reserve Bank of India, Mumbai, pp. 4.
} 
In the years preceding the signing of the GATS agreement, very few licenses for new foreign bank branches were granted, and the presence of foreign banks in India was limited. On March 31, 1994 there were 24 foreign banks with 156 branches in India. Most of these banks, however, had begun operations before India's first nationalization of private banks in April 1969, and only seven new branches had opened since 1990. Moreover, most of India's 575 districts did not have a foreign bank, as roughly $75 \%$ of these foreign bank branches were concentrated in districts encompassing India's three largest cities: Delhi, Mumbai, and Kolkata.

In eight years following the acceptance of GATS, however, 17 new foreign banks and 89 new foreign bank branches were opened in India bringing the total number foreign banks to 41 with 212 branches as of March 2002. ${ }^{7}$ The expansion of foreign banks also increased their representation outside of India's most populous cities, as the number of districts with a foreign bank increased from 18 to 26, and foreign banks' share of total long-term loans increased as well. In March 1994, foreign banks accounted for five percent of all outstanding long-term loans. With their expansion of branches, their share of long-term loans increased and averaged roughly eight percent from 19961998, and ten percent from 1999-2001. More importantly, some back of the envelope calculations suggest foreign bank entry was sizeable in the eight districts receiving their first foreign bank. By 2003, foreign banks accounted for roughly 5.5\% of long-term loans in these districts.

\section{Data Description}

The data used to identify the location and date of opening for each foreign bank in India is the Directory of Bank Offices published by the Reserve Bank of India (RBI). Providing the location, name, opening date, and closing date for every bank office in India, the data set is used to construct a complete annual directory of all banks in India from 1988-2004.

Using this data, it is possible to map out the timing and location of arrival for the new foreign

733 foreign bank branches closed during this time period, so the net change was only 56.17 of these closures were from ANZ Grindlays Bank Ltd. and five from Standard Chartered Bank in 1998 and 1999. 
banks. Table I shows the number of foreign banks by district and year from 1990-2002. In the top half of the table are the 18 districts that already had a foreign bank before 1991. These include the three districts with very large metropolitan centers: Delhi, Greater Mumbai, and Kolkata. In the bottom half are the eight districts that received their first foreign bank during India's financial liberalization. As can be quickly seen, the overall increase in foreign bank branches largely coincides with the signing of the GATS in 1994, but the actual timing of entry across these eight districts is staggered across years. The district location of new foreign banks is mapped in Figure 1 which highlights the eight districts that receive their first foreign bank between 1991 and 2002. The eight districts are relatively dispersed across India, spanning seven of India's 35 states. $^{8}$

The bank location data are matched up to the Prowess data set compiled by the Centre for Monitoring Indian Economy (CMIE). Prowess is a panel data set of firms from 1988-2002 where Indian and foreign firms with assets plus sales greater than 40 million Rupees (approx. \$900,000) are included in the data set. The data set provides the annual financial and accounting data of each firm along with descriptive variables including the ownership, year of incorporation, and registered address. Using each firm's address, it is possible to track their financial status at the district level and to merge this data to the district location of the new foreign banks in India. CMIE compiles the financial data using the audited annual accounts that all registered companies in India must submit to the Registrar of Companies. The cutoff level of firm size in the Prowess dataset seems to be an arbitrary point chosen to limit the size of the database. For the remainder of this paper, the analysis is restricted to non-financial, domestic firms included in the Prowess data by 1991, and all financial variables from Prowess are adjusted for inflation using India's consumer price index. ${ }^{9}$

Table II provides pre-reform summary statistics of the firms included in Prowess broken

\footnotetext{
${ }^{8}$ Citibank and Hong Kong \& Shanghai Banking (HSBC) were responsible for half of the new foreign bank branches in the eight districts. Other banks opening branches in these districts were ABN AMRO, American Express Bank Ltd., ANZ Grindlays, BNP Paribas, Crédit Lyonnais, Deutsche Bank (Asia), Société Générale, and Standard Chartered. Each had pre-existing branches elsewhere in India at the time of entry in the eight districts.

${ }^{9}$ Appendix Table I provides an exact description of which observations are dropped from later regressions. The appendix also provides details on how firm locations are determined within Prowess.
} 
down into three categories based on a firm's location. The first column reports summary statistics for firms found in the 18 districts with a foreign bank presence by 1991. These districts are more densely populated and heavily banked than all other districts. Firms in these districts are also twice as large on average, in terms of total assets, than all other firms in India which are reported in the other two columns. The second column provides statistics for firms in the eight districts that receive their first foreign bank from 1991-2002, and column three provides the summary statistics for firms found in districts still without a foreign bank by the end of 2002. The eight districts with a new foreign bank are also more densely populated and heavily banked than the remaining 154 districts that do not receive a foreign bank by 2002, but not nearly to the extent as districts already having a foreign bank. The main comparison of interest in this paper is between firms located in the eight districts receiving their first foreign bank in the 1990s to those located in districts without a foreign bank. Among firms in these districts, bank credit accounts for roughly $2 / 3$ of total borrowings. Short-term bank credit, which is defined as all cash credits, bank overdrafts, and working capital loans from banks with maturity less than a year, accounts for roughly $1 / 2$ of their bank borrowings, while longterm loans with maturity of one year or more from banks and financial institutions (FIs) account for the other half of bank borrowings in each type of district.

The distinction between long-term 'bank' and 'FI' loans is important as it allows for a partial separation of loans provided by domestic and foreign banks. While the Prowess data does not provide a direct measure of loans from foreign banks, these loans will be included, along with loans from domestic commercial banks, in a firm's stock of 'bank' loans. Only about $44 \%$ of firms in districts without a foreign bank had such loans in 1993 as India's commercial banks typically do not provide many long-term loans. 'FI' loans, however, report firms' loans from India's development banks and will capture the indirect effects of foreign entry on domestic lending patterns. These development banks are large domestic entities and the primary providers of long-term loans in India, and because they specialize in long-term loans, they are particularly likely to be affected by the entry of foreign 
bank. ${ }^{10}$ According to the Annual Accounts Data for Commercial Banks published by the RBI, long-term loans accounted for 70\% of total loans for Citibank and HSBC from 1996-2001.

\section{Empirical Strategy and Identification Assumptions}

The basic OLS specification used in this paper is the following:

$$
y_{i, d, t}=\beta_{0}+\beta_{1} \text { Foreign Bank }_{d, t}+\alpha_{i}+\delta_{t}+\varepsilon_{i, d, t}
$$

The dependent variable is a firm-level outcome variable $y$ for firm $i$, located in district $d$, in year $t$. The variable $y$ will entail measures of firms' outstanding stock of loans from banks and FIs, and the different financial measures used are discussed below. The Foreign Bank variable is an indicator for the presence of a foreign bank in district $d$ in year $t$ that is turned on for all firms in the district if a foreign bank was present in that year. All subsequent findings are similar when the district-level share of foreign banks is used instead of an indicator. However, the indicator of foreign bank entry is preferred since theory indicates that the mere entry of the foreign lender is sufficient to induce a segmentation of the market and exacerbate information asymmetries (Dell'Arricia and Marquez, 2004; Sengupta, 2007; Gormley, 2007). A full set of firm dummies, $\alpha_{i}$, absorb any fixed differences in firms' use of loans such that the coefficient of interest, $\beta_{1}$, is estimated only using within firm changes. This ensures that firm-specific or location-specific characteristics that do change over time will not drive the empirical findings. Moreover, the time dummies, $\delta_{t}$, control for any country-level trends in lending patterns that may be caused by other changes in government policy or financial deregulation. Finally, because the variation of foreign entry occurs at the district level, the standard errors are clustered at the district.

In this base specification, the effect of foreign bank entry is captured by the coefficient $\beta_{1}$ which is estimated using the changes in the borrowing patterns of firms located in the eight districts

\footnotetext{
10 The development banks include the Industrial Development Bank of India (IDBI), Industrial Finance Corporation of India (IFCI), and Industrial Credit and Investment Corporation of India Limited (ICICI). FIs were established in the 1950's and 1960's with the express purpose of providing long-term financing to firms..
} 
that receive their first foreign bank from 1991-2002 relative to firms in districts that never receive a foreign bank. There are two main advantages of this within-country analysis over the more standard approach of using cross-sectional, country-level analysis. First, the panel specification makes use of the staggered timing of entry by foreign banks between 1994 and 2001, and the coefficient $\beta_{1}$ is estimated using only changes in borrowing patterns at the time of foreign bank entry within each district. This panel variation and the inclusion of firm-level fixed effects eliminates the concern that fixed differences across districts, such as differing labor market regulations or financial development, will cause an omitted variable bias. ${ }^{11}$ Second, the use of within-country variation ensures that any findings for $\beta_{1}$ are attributable to the entry of the foreign bank rather than other country-level financial reforms implemented during the early 1990s. The impact of such country-level reforms would by absorbed by the year dummies, and the effect of foreign bank entry will be properly identified under the assumption that the trend in use and size of firms' loans in these eight districts would have been the same as those in the control group in the absence of the foreign banks' entry. ${ }^{12}$

The primary control group used is all firms found in districts that did not have a foreign bank at any point from 1991-2002. Firms headquartered in the 18 districts with a pre-existing foreign bank are dropped from the regression. As shown in Table II, these districts are likely to be a poor control group since they are significantly more urban and contained firms that were much larger on average. As shown in Section $\mathrm{V}$, however, including these 18 districts does not significantly alter the main findings. As a robustness check, the regressions are also run using a smaller control group consisting only of firms found in the nine districts that receive their first foreign bank in 2003 and 2004: Aurangabad, Bhopal, Faridabad, Lucknow, Nagpur, Patna, Rajkot, Surat, and Thane. These nine districts potentially provide a better control group in that one might consider them "next in line" for foreign bank entry and hence, very similar to the eight districts that receive their foreign bank earlier.

\footnotetext{
${ }^{11}$ See Besley and Burgess (2004) for more information on how labor market regulations vary across Indian states. 12 There, however, would still be a bias if other country-level financial reforms had a differential impact across districts that is correlated with both the location and timing of foreign bank entry across India. While such a bias seems unlikely, Section V.C. conducts a number of robustness checks to address this concern.
} 
The basic specification in equation (1), however, does not allow us to test whether foreign bank entry differentially affects firms. This is done using a second specification, equation (2), that includes the interaction, Foreign Bank $\times \mathrm{ROA}$, where $\mathrm{ROA}$ is the demeaned average percent return over total assets of firm $i$ from 1991-1993. Profits are measured using profit after taxes net of nonrecurring transactions. A full set of year and profit interactions, $\delta \times \mathrm{ROA}$, are also included to allow firms across India to trend differently as a function of their past profitability.

$$
y_{i, d, t}=\beta_{0}+\beta_{1} \text { Foreign Bank }_{d, t}+\beta_{2}\left(\text { Foreign Bank }_{d, t} \times \mathrm{RO} A_{i}\right)+\alpha_{i}+\delta_{t}+\left(\delta_{t} \times \mathrm{RO} A_{i}\right)+\varepsilon_{i, d, t}
$$

In this second specification, $\beta_{1}$ still describes the main effect of foreign bank entry since $\mathrm{RO} A$ is demeaned, whereas, $\beta_{2}$ describes the marginal effect of having a higher $\mathrm{RO} A$ beforehand. Inclusion of the interaction of Foreign Bank $\times \mathrm{ROA}$ tests whether a firm's profitability matters more for credit access after foreign banks enter the district, under the assumption that a firm's past ROA is a positive predictor of future potential. ${ }^{13}$ This allows us to assess whether foreign bank entry is associated with a reallocation of credit from less profitable to more profitable firms, as would be indicated by $\beta_{2}>0$. Moreover, if there is a drop in credit driven predominately by fewer loans allocated to politically connected, unprofitable firms, this would also be indicated by $\beta_{2}>0$.

Finally, it is implicitly assumed that the effect of foreign bank entry is localized and realized predominately by firms headquartered in the district with a foreign bank. Both specifications presume that firms in India borrow from banks located near their registered address, and that these banks are located in the same district. In general we expect this to hold as empirical work regarding lending relationships in other countries has demonstrated the average distance between firms and their bank is usually quite small. ${ }^{14}$ However, even if this assumption is not fully true, this would only

\footnotetext{
${ }^{13}$ Firms' average ROA from 1991-1993 is in fact positively correlated to ROA levels from 1994-2002. Pre-entry ROA is used rather than actual ROA since profits after 1993 are an endogenous outcome of foreign bank entry. 14 Analyzing small firms in the U.S., Petersen and Rajan (2002) finds that the average distance between a firm and its main bank was 67.8 miles in 1993, and the median distance was five miles. The Indian districts included in this sample had an average size of 2,457 square miles. While the U.S. firms sampled were on average six times smaller than the firms found in the Prowess data, it is likely the Indian firms also borrow locally as the positive relation between distance and borrowing costs are greater in a developing country such as India.
} 
bias the results against finding an effect of foreign bank entry. If firms borrow from outside their district, then firms located outside the eight treated districts may in fact be 'treated' causing the estimates to understate the true effect. Moreover, the ability to borrow from banks outside the district will only mitigate the local impact of foreign bank entry thus making it more difficult to discern an impact of foreign bank entry at the district level.

To measure firms' access to loans, a number of dependent variables, $y$, will be used. First, to test the effect on the amount of loans a firm reports, three different variables will be used: the stock of long-term commercial bank loans (Bank Loans), the stock of loans from domestic development banks (FI Loans), and the stock of loans from both commercial and development banks (Total LongTerm Loans). All three measures are normalized by firms' total assets as they stood in the beginning of the sample in 1991. Second, a set of indicators that equal one for firms with a loan from the given source are used to test for changes in the likelihood of a firm having a loan. While the two sets of financial measures are similar in nature, their distinction is important. The first set will capture whether firms in districts receiving a foreign bank experience a relative change in the amount of financing they receive, while the second set of indicators will test for whether a firm's likelihood of having a loan is affected by foreign bank entry.

\section{OLS Estimates}

The OLS estimates of the relation between long-term loans and the presence of a foreign bank are reported in Table III. Columns (1)-(4) report the coefficients using an indicator for having a long-term loan as the dependent variable, while columns (5)-(8) report the coefficients when the dependent variable is the stock of total long-term loans normalized by assets.

Rather then being a boon for domestic firms, foreign bank entry is associated with a reduction in domestic firms' likelihood of having long-term loan that is unrelated to firms' past profits. In the base regression with all firms and no additional controls or interactions [column (1)], foreign bank entry coincides with a 7.6 percentage point drop in firms' likelihood of having a long- 
term loan relative to firms located in districts without a foreign bank. The drop in the number of firms with a long-term loan is relatively large and coincides with the entry of foreign banks as shown in Figure 2. Moreover, inclusion of the $R O A$ interactions [column (2)] demonstrate that the decrease is largely unrelated to firms' ROA, and if anything, there is weak evidence a firms' ROA is marginally less important following foreign entry. The decline in loans is robust to including industry-year interactions [column (3)] and restricting the sample to eventually "treated" districts [column (4)].15 .

There is evidence, however, that foreign bank entry is associated with an increase in the relative importance of firms' $R O A$ in the amount of long-term financing allocated. In regressions that use the stock of long-term loans normalized by assets as the dependent variable [Table III, columns (5)-(8)], a higher ROA corresponds to an increase in the loan to asset ratio for firms in districts with a foreign bank relative to firms in districts without a foreign bank. The magnitude of the coefficient in column (6) implies that a one standard deviation increase in firms' $R O A$ is associated with an increase in their loan to asset ratio that is approximately $1 / 10$ standard deviations larger when a foreign bank is present in their district. However, there is no significant evidence of an average decrease in loan sizes. The loan-asset ratio being a noisier measure of credit relative to the indicator may explain why I find a reduction in average number of loans but not average size of loans.

Overall, the estimates of Table III indicate that the more profitable firms see an increase in their relative amount of loans, while other firms see a drop in their likelihood of having a long-term loan. The question remains, however, as to whether this reallocation is efficient. In this regard, the drop in loans does not appear to be driven by a decline in loans allocated to only the most unviable, politically-connected firms. This would yield a positive coefficient for the marginal effect of a firm's $\mathrm{RO} A$, not a negative coefficient as seen in columns (1)-(4) of Table III. Instead, the decrease in credit seems to be unrelated to firms' potential, and if anything, the relation is the opposite of what

\footnotetext{
${ }^{15}$ While not shown, the negative relation between foreign bank entry and firms' likelihood of a loan is also robust to the use of a fixed effects probit estimation. For this paper, however, the linear probability model is preferred as the probit model suffers from large small-sample biases when estimated with fixed effects (Greene, 2004) in what is known as the 'incidental parameters problem'.
} 
one might expect. If some firms do receive better financial services after entry, part of the decline in loans could also be demand driven if local domestic firms within the same industries face greater competition in their output market. Given that these are relatively large firms, however, such local changes are unlikely to affect the aggregate demand for their output, and a robustness check in Section V.C. also suggests the decline in loans is not demand-driven.

\section{IV.A. "Direct" versus "Indirect" Effects}

To better understand where the changes in loan allocations are coming from, the regressions are now conducted separately for loans from banks and FIs. Again, the regressions pertaining to bank loans will proxy for the "direct" effect of new foreign bank loans, while the FI loan regressions will capture the "indirect" effect of foreign bank entry on the domestic loans from India's development banks. The regressions for bank and FI loans are reported in Tables IV \& V.

In Table IV, we see that the decrease in the likelihood of having a long-term loan is driven entirely by a fall in FI loans [columns (5)-(8)] rather than loans from commercial banks [columns (1)(4)]. This implies that competition from foreign banks indirectly affects the allocation of credit by India's domestic development banks. Again, a firm's $R O A$ does not appear to have any effect on whether it is less likely to receive an FI loan. Therefore, there does not appear to be any evidence to support the hypothesis that domestic lenders respond positively to competition by adopting new screening technologies and improving their credit allocation. Instead, domestic development banks respond to the competition from foreign banks by systematically reducing the number of domestic firms they extend long-term loans to, regardless of their potential, and this decrease in loans from the domestic banks is not offset by an increase in loans from foreign banks.

It is difficult to discern exactly where the domestic capital went. One possible explanation is that FIs raised less capital on external markets via the issuance of bonds, commercial paper, etc. While data is only available beginning in 1996, the real value of external capital raised by development banks was constant from 1996-1998 and declining thereafter. Another potential explanation is that 
bank capital was redirected elsewhere. From 1992-1993, 24\% of bank deposits were held as government securities, but from 1994-1998, it increased to $29 \%$, exceeding the statutory requirement of $25 \%$. Data limitations, however, do not allow me to test whether either of these changes were driven by development banks located in districts with new foreign banks.

In Table $\mathrm{V}$, we see that the relative increase in importance of firms' $\mathrm{RO} A$ for the amount of loans is driven primarily by an increase in slope for bank loans [columns (1)-(4)] rather than FI loans [columns (5)-(8)]. This suggests the increase in loans to more profitable firms is driven by new loans from the foreign banks rather than domestic banks. Because domestic commercial bank loans are also included in the measure of 'bank' loans, however, the increase in relative importance of $\mathrm{RO} A$ may also be driven by new domestic commercial bank loans. This might occur the domestic commercial banks improved efficiency following foreign bank entry. However, if this were true, we should also expect to find a similar improvement in efficiency for domestic development banks, but as shown in Table IV, there is no such evidence. Moreover, the reallocation of bank loans appears driven by lending patterns consistent with the 'cream-skimming' behavior and targeting of less informationally-opaque firms that is generally associated with foreign banks rather than domestic banks. This is evidence is discussed in Sections IV.B. and VI.A.

\section{IV.B. Evidence of 'Cream-Skimming'}

Contrary to a general reallocation of credit from less to more profitable firms, the positive interaction in Table $\mathrm{V}$ appears driven by an increase in bank loans to only the top ten percent of firms in terms of $R O A$. It is easy to see this in Figure 3, which breaks down the trend in bank loans/assets of firms from 1991-2002 based on their ROA from 1991-1993. As seen in Figure 3, the trend in loans to the most profitable ten percent of firms was relatively flat from 1991-1995. Beginning in 1996, however, there is a very large growth in loans for the top ten percent in districts with a foreign bank, while the top ten percent in other districts do not show any increase in loans. The increase in loans to more profitable firms is restricted to the top ten percent, however, as there is 
no evidence that foreign bank entry is associated with an increase in loan amounts for firms with an $\mathrm{RO} A$ above the median but not in the top ten percent or for firms with an $\mathrm{ROA}$ below the median.

The estimates in Table VI confirm that the positive interaction on loan sizes is caused predominately by the top ten percent of firms. In columns (1)-(3), the top ten percent of firms in terms of $\mathrm{ROA}$ are dropped from the regressions. The positive effect on the size of loans to more profitable firms seen in Table $\mathrm{V}$ is now completely gone, supporting the finding that the earlier results were primarily driven by an increase in bank loans to very profitable firms. The increase in loans also seems to be primarily caused by only the largest firms. Dropping firms with assets in 1991 exceeding the median, as done in columns (4)-(6) also eliminates the increase in loans.

\section{IV.C. Interpreting the OLS Estimates}

Overall, the OLS estimates are supportive of models incorporating asymmetric information. The increase in loans to the most profitable ten percent of firms is suggestive that these firms were under-financed in the closed economy, and that foreign bank entry improves the allocation of credit by targeting more loans to these firms. However, the increase in loans appears limited to small subset of profitable firms, which is consistent with theories that asymmetric information induces 'creamskimming' behavior by foreign banks. At the same time, foreign bank entry also led to a systematic reduction in long-term lending by the domestic development banks that is not offset by a corresponding increase in loans from foreign banks. This finding is consistent with models that suggest foreign bank entry may adversely affect some firms. While part of this decline in credit may be the consequence of an efficient reduction in loans to very unprofitable or politically-connected firms, the extent of the drop and its non-relation to a firm's past profits is suggestive that some viable domestic firms were also less likely to receive a loan after entry. Additionally, the findings are similar if I instead restrict the sample to listed firms and use pre-entry measures of Tobin's Q as a proxy for a firm's future potential instead of past profits. Overall, there is no evidence that the decline in domestic loans is larger among underperforming firms. 
These findings have implications for financial policy in LDCs, which in recent years has increasingly trended towards the allowance of greater foreign bank entry. While the potential benefits of foreign bank entry are many, the evidence suggests that information asymmetries may prevent many firms in these economies from realizing these benefits. This finding parallels an existing literature that examines the comparative disadvantage of large banks in the production and use of 'soft' information, and the unanticipated consequences that greater competition may have on the lending relationships that small and medium-sized entrepreneurs rely on. Overall, this evidence suggests that it may be necessary to adopt additional policies-beyond allowing foreign banks entry-to increase efficiency and improve credit access in LDCs. The evidence also suggests the sequencing of reforms in developing countries may be important as well. Policies that promote a well-developed domestic financial market may be necessary prerequisites to foreign bank entry.

\section{Robustness Checks \& IV Estimates}

While the initial regressions are supportive of predictions that additional competition from foreign banks will induce a reallocation of credit when information asymmetries are large, one might be concerned about a potential selection bias in the OLS estimates. Since foreign banks endogenously chose where to locate new branches in India, it is possible the foreign banks selected into districts that were either already trending differently in bank or FI loans or were going to trend differently in the future for reasons other than the entrance of the foreign bank.

\section{V.A. Testing for Pre-trends}

To test for a pre-existing trend in bank and FI loans, two variables are added to the basic regressions of Tables III-V. The first variable is an indicator, fake, that turns positive in the three years prior to the entrance of a foreign bank. For example, in Ludhiana where the first foreign bank arrives in 2001, this variable is equal to one in years 1998-2000, and zero all other years. The second variable added is the interaction fake $\times R O A$. Results of this specification are shown in Table VII. 
If the most profitable firms were already seeing an increase in their bank loans in the three years prior to the foreign bank's arrival, then we would find a positive coefficient for the interaction term, fake $\times R O A$. Additionally, if domestic firms in the foreign bank districts were already exhibiting a reduction in their access to development bank loans before the foreign bank's arrival, we should find a negative coefficient for fake in the regressions using an indicator for FI loans as the dependent variable. However, as shown in Table VII, the increase in bank loan amounts to the most profitable firms [columns (1)-(4)] and the reduction in FI loans to all firms [columns (5)-(8)] are not present in the three years before foreign bank entry. In neither case can we reject the null hypothesis that the point estimate for fake or fake $\times R O A$ is zero. There is no evidence that foreign banks selected into districts with pre-existing differential trends in bank or FI loans.

Moreover, both the increase in bank loans to the most profitable firms and the drop in FI loans appear to occur one to two years following foreign bank entry within each district. Figure 4, Panel A plots the point estimates from an OLS regression of bank loans/assets onto indicators for years pertaining to foreign bank entry for firms with an $R O A$ in the top ten percent. As shown in Figure 4, there is no evidence of an increase in bank loans/assets in the years preceding foreign bank entry or in the year of actual entry. However, one year following entry, bank loans/assets increase, and the increase becomes and stays significant at the five percent level beginning two years after foreign bank entry. Figure 4, Panel B plots the point estimates from a similar regression using all firms and an indicator for FI loans as the dependent variable. Again, the point estimates indicate the decline in FI loans begins approximately one to two years after initial entry.

\section{V.B. IV Estimates}

However, there is still the concern that foreign banks could have selected into districts that were going to trend differently in the future for reasons unrelated to the actual entry.

A review of press releases of the foreign banks establishing new branches in India during the late 1990s suggests new branch locations in India were chosen to decrease the distance to existing 
borrowers and to establish a presence in high-growth cities. Inaugurating the opening of a new branch in Surat in 2004, Sanjay Nayar, Citigroup Country Officer for India, stated "We're very happy to move closer to our clients..." Regarding the opening of a new branch in Vadodara in 2005, Naill Booker, CEO of HSBC -- India, stated, “The markets in western India hold enormous potential for growth and there are huge opportunities for us..." While the location choice based on existing clients is unlikely to pose an identification problem, the selection into high-growth districts could cause a positive bias in the OLS estimates if these districts would have seen a growth in loans even in the absence of foreign banks. Or, this selection into high-growth districts could also cause a negative bias if the rapid growth by new industries (e.g. software) in these districts coincides with slower growth rates for firms in older, more established industries.

To address this potential identification problem, the pre-1994 presence of foreign firms is used as an instrument for the location of new foreign banks. I assume that foreign banks are more likely to enter districts with firms from their home country to preserve pre-existing relationships or take advantage of their competitive advantage in obtaining information about the firms in their home country. This tendency for foreign banks to follow their customers abroad has been noted in a number of countries, ${ }^{16}$ and seems to occur in India also. Within the sample of data, there are 52 foreign-owned firms spread across 26 of the 162 districts. Five of the eight districts that receive their first foreign bank during the 1990s have a foreign-owned firm present in 1993.

To test the relation between the location of foreign banks and foreign-owned firms, the following first stage regression is used:

$$
\text { Foreign Bank }_{d, t}=\text { const. }+ \text { Foreign Firm }{ }_{d, 1993} \times \text { Post }-1993_{t}+\alpha_{i}+\delta_{t}+\varepsilon_{i, d, t}
$$

The instrument for Foreign Bank is the interaction between a district level indicator variable for having a foreign-owned firm present in 1993, Foreign Firm, and a post-1993 year indicator. This is a

\footnotetext{
${ }^{16}$ Sabi (1988) finds a positive correlation between the amount of U.S. FDI and banking assets in 23 less-developed countries from 1975-1982. Yamori (1998) finds that Japanese financial companies tend to invest in countries with greater amounts of Japanese FDI. Brealey and Kaplanis (1996) find a positive correlation between the number of foreign banks present in a country and the amount of FDI from the parent country of the foreign banks.
} 
firm-level regression with firm and time dummies, and the standard errors are clustered at the district level. The results of the first stage are reported in Table VIII. As can be seen, the presence of a foreign-owned firm in 1993 is a positive and significant predictor of a foreign bank being present in the years 1994-2002. The estimates imply that the presence of foreign-owned firm in 1993 increased a districts' likelihood of receiving a foreign bank after 1994 by about 34 percentage points relative to districts that did not have a foreign-owned firm.

In order for the instrument to be valid, however, the location of foreign firms, in itself, should be uncorrelated with the borrowing trends of domestic firms. While the original location choice of foreign firms was also probably strategic, ${ }^{17}$ this assumption seems plausible in that the median year of incorporation for foreign firms used in the sample is 1974, nearly 20 years prior to the liberalization of the mid-1990s. Therefore, the location of foreign-owned firms is less likely to be directly correlated to domestic lending patterns in the mid- to late 1990s than the location choice of the new foreign banks. The IV estimates reported below are also very similar when the sample is restricted to foreign firms established at least ten years prior to India's liberalization in 1994. Using only these older, foreign firms further limits endogeneity concerns regarding the location choice of recently established foreign firms. These estimates are available from the author upon request.

Moreover, there is no evidence that domestic firms in districts with a foreign firm were trending differently in their use of long-term loans in the five years prior to the signing of GATS in 1994, which might occur if the presence of the foreign firms generates spillover effects (e.g. creation of infrastructures, etc.) that indirectly affect domestic borrowing patterns and growth. This is seen in Figure 5, which plots the percentage of firms with an FI loan and the average bank loan to asset ratio of firms from 1989-2002. Bank loans show a similar downward trend in the five years prior to foreign bank entry in both districts with and without a foreign firm in 1993, and the number of firms with FI loans was trending up in both types of districts from 1989-1993. Therefore, in order for the

\footnotetext{
${ }_{17}$ The location of foreign direct investment (FDI) within the U.S. suggests foreign firms tend to locate in areas with lower taxes, higher per-capita incomes, lower wages, and more extensive transportation infrastructures (Coughliin, Terza, and Arromdee 1991; Hines, 1996). Cheng and Kwan (2000) find similar results for China.
} 
instrument to violate the exclusion restriction, one must imagine a story where a foreign firm's presence in India would just happen to induce a direct change in domestic bank loans at the time of foreign bank entry within each district, but not before. Given there does not appear to be any other changes in government policy that both increases the importance of foreign firms and coincides with the timing of foreign bank entry within each district, the instrument appears valid. Finally, there is also no evidence that the presence of foreign firm in 1993 is correlated with other changes in the local banking environment after 1993, including the growth of domestic private banks across India.

With the instrument seeming to satisfy the identification assumptions, I now proceed to the IV estimates of equation (2). The interaction Foreign Firm $\times$ Post-1993 is used to instrument for the location of foreign banks, Foreign Bank, and the interaction Foreign Firm $\times$ Post $-1993 \times R O A$ is used to instrument for Foreign Bank $\times R O A$. The IV estimates are reported in Table IX.

The IV estimates confirm the OLS estimates. The arrival of a foreign bank is still associated with a drop in the average firm's likelihood of receiving a long-term loan [Table IX, column (3)]. The IV estimates suggest foreign bank entry is associated with a 12.4 percentage point reduction in firms' likelihood of having either a loan, which is larger than OLS estimate of 7.6 percentage points and statistically significant at the 10 percent level. ${ }^{18}$ The reduced form estimates (not presented) also show a significant drop in loans after 1993 in districts with a foreign firm prior to 1993. Moreover, foreign bank entry is still associated with a positive and significant increase in the marginal importance of $R O A$ for bank loan sizes [Table IX, column (5)], and the magnitude of the effect is similar to the OLS estimate. The IV estimates are also robust to including industry-year interactions as done in some of the OLS specifications.

\section{V.C. Additional Robustness Checks}

Overall, both the drop in firms' likelihood of having a long-term loan and the increase in the relative importance of firms' past ROA in determining the size of bank loans after foreign bank entry

${ }^{18}$ The less significant IV estimates (relative to the OLS) are not surprising since the IV estimation only uses preversus post-1993 variation, which fails to capture the staggered entry of foreign banks across districts after 1993. 
are robust to using a number of different specifications and control variables. The inclusion of urban-year interactions or state-year interactions do not alter the findings, indicating that the selection of foreign banks into relatively more urban states or districts are not driving the findings. The results are also robust to controlling for changes in a variety of firm-level characteristics over time, such as size and export intensity. Dropping firms that permanently exit the data set before 2002 or further restricting the data to balanced panel of firms also does not impact the basic findings.

Including firms located in the 18 districts with pre-existing foreign banks also does not change the OLS or IV results, though a number of the estimates are no longer significant at conventional levels. However, the inclusion of these districts confounds the effect estimated by the indicator Foreign Bank as some districts, such as Kozhikode and South Goa, exhibit a complete exit by foreign banks between 1991 and 2002. With their inclusion, the basic specification no longer just estimates the effect of foreign bank entry but the average effect of entry and exit. There is no reason to believe the two events should induce equal effects as the foreign banks that exit are likely to be much different than the new foreign banks. Excluding the districts exhibiting a complete exit by foreign banks between 1991 and 2002, I again find a significant negative effect of foreign bank entry on FI loans and a significant positive effect on the importance of past ROA for bank loans. Moreover, restricting the sample to districts with pre-existing foreign banks also does not change the main results. Within these 18 districts, an increase in foreign banks' total share of branches in a district is associated with a decline in the likelihood of firms having a long-term loan.

The findings also do not appear to be driven the increase in domestic private banks across India that occurred following a wave of banking deregulation in 1993. Assets held by private banks in India increased from 4.5 percent in 1993 to 12.1 percent in 2001. The entry of private banks could bias the above estimates if their growth across India is correlated with both the location and timing of foreign bank entry across India. However, this is unlikely as the initial growth of private banks preceded foreign bank entry and was far more widespread. Nearly half of India's districts saw an increase in private banks between 1992 and 2002, and the growth rate of private banks in districts 
with a new foreign bank was similar to that of districts that did not receive a foreign bank until after 2002. On average, domestic bank branches grew 2.1\% each year from 1994-2001 in districts that received a new foreign bank during the sample period, which is similar to the $1.7 \%$ growth rate for districts that did not receive a new foreign bank until after 2002. The difference is not statistically significant. Moreover, the inclusion of district-level controls for the total number of domestic private banks or other non-foreign banks do not alter the main findings.

For the same reason, changes in the regulation of development banks in the early 1990s are also unlikely to explain the above findings. Prior to 1991, India's domestic development banks frequently engaged in government 'directed' lending programs and were shielded from competition via regulatory barriers to entry. The subsidization of FIs was curtailed in the early 1990s and regulations inhibiting the provision of long-term loans by other banks were removed as part of a general reform to put FIs and commercial banks on equal footing in terms of regulations, supervision, and operations. However, these reforms pre-date the entry of foreign banks into Indian districts by 2-8 years, and they applied uniformly to development banks across all Indian districts. Instead, the absence of banking competition in India prior to 1991 likely contributed to the reallocation of credit following foreign bank entry since the development banks were particularly inexperienced at effectively screening potential clients. Moreover, similar 'directed' lending programs and regulatory barriers are quite common in many LDCs that allow greater foreign bank entry suggesting that the experience of India's development banks may not be all that unique.

Another concern might be that the drop in long-term credit is caused by the growth of industries concentrated in the treated districts. While industry-year interactions would pick up any differential trends for these industries, one might still be concerned that their growth could have an indirect effect on borrowing by other local firms. One such example could be the software industry, which is typically less dependent on long-term capital and experienced significant growth in the late 1990s. Five of the eight treated districts had software-related firms by 2002 compared to only 14 of 
the 154 non-treated districts. However, the estimates are robust to restricting the control group to only districts with software industries by 2002 .

The observed decline in domestic loans also appears to reflect a decrease in the supply of credit rather than a change in demand. If foreign firms or the most profitable domestic firms receive better financial services after entry, local domestic firms within the same industries as these firms are likely to face greater competition. In this case, the decline in loans could be demand-driven as domestic firms respond negatively to increased competition from other firms. However, this does not seem to be the case. Excluding domestic firms identified in the same industry and district as foreign firms does not change the estimates. Excluding firms found in the same industry as treatment firms with an $R O A$ in the top ten percent also does not affect the estimates.

Finally, the findings also do not appear driven by a shift to alternative capital markets, such public equity markets, which were developing quite rapidly in India during the 1990s (Gopalan and Gormley, 2007). There is also no evidence to indicate firms' equity issuances increased following foreign entry. There is also no evidence of an increase in the amount of short-term loans, commercial paper, debentures, fixed deposits, or trade credit after foreign bank entry. There was weak evidence, however, of an increase in the amount of corporate loans used by firms after foreign entry, particularly among group-affiliated firms. This would be consistent with group affiliated firms mitigating the drop in bank credit by relying more on internal capital markets after foreign bank entry. These estimates are available from the author upon request.

\section{Differential Impact and Firm Performance}

\section{V.A. Firm Size, Tangiblility, and Group Affiliation}

If information asymmetries play an important role in explaining the reallocation of credit following foreign bank entry, then we would expect foreign bank competition to affect firms with opaque informational structures more than other firms. Moreover, firms with fewer tangible assets 
may also be more likely to lose access to credit after foreign entry if domestic lenders rely more on collateral when making lending decisions rather than investing in the costly screening technologies to identify creditworthy firms. To test these hypotheses, the sample is divided into firms based on measures of size and 'tangibility' in 1991 prior foreign bank entry, where size is measured using total assets and a firm's ‘tangibility' is measured as in Berger, Ofek, and Swary (1996). ${ }^{19}$

In Table X, OLS estimates of the impact of foreign bank entry on the amount of long-term loans are reported separately for firms in the bottom and top quartile of 'size' and 'tangibility'. ${ }^{20}$ Consistent with the hypothesis that more informationally opaque firms may be adversely affected by foreign entry, there is a decrease in the average size of loans allocated to smaller firms after foreign entry, but no significant effect on larger firms [columns (1)-(2)]. Moreover, there is a decrease in the size of loans allocated to firms with less tangible assets following foreign bank entry suggesting lenders relied more heavily on collateralized loans following foreign bank entry [columns (3)-(4)]. Again, there is no evidence that the decline in loans to smaller, less tangible firms is related to past profitability, but there is some evidence that the allocation of credit to high tangible firms became more efficient after entry. As seen in column (4), among firms with greater tangible assets, firms with a stronger profitability track record received relatively larger loans after foreign bank entry.

In another test of the asymmetric information hypothesis, the sample is divided into firms associated with a business group and all other non-group firms. ${ }^{21}$ The information hurdle faced by lenders is likely higher for firms associated with a business group because of their complicated networks and the relative ease of diverting funds within the group. Given this, we should expect to see foreign bank competition have a stronger negative effect on the amount of credit allocated to

\footnotetext{
${ }^{19}$ Specifically, Berger, Ofek, and Swary (1996) use data on proceeds from discontinued operations of U.S. firms to define tangibility as $(0.715 \times$ receivables $+0.547 \times$ inventory $+0.535 \times$ fixed assets + cash $) /$ total assets.

20 The results are robust to dividing the sample at different cutoffs.

${ }^{21}$ Groups in India are typically controlled via a complicated network of company shareholdings, and their existence pre-dates liberalization in 1947. [See Dutta (1997) and Ghemawat and Khanna (1998) for more details.] CMIE tracks group affiliation in Prowess through "continuous monitoring of company announcements and a qualitative understanding of the group-wise behavior of individual companies" (Prowess Help Files, Data Dictionary). Khanna and Palepu (1999) find the CMIE classification to be consistent with other available lists of Indian groups.
} 
these firms. If foreign banks face greater difficulties in screening group-affiliated firms, then we should also expect to find foreign banks more likely to target non-group firms. Both of these predictions in fact seem to be true in the example of India.

As seen in Table XI, the decrease in firms' likelihood of having an FI loan is larger among the group-affiliated firms [column (1)] rather than non-group firms [column (3)] and again unrelated to firms' past profitability. This drop in credit to group affiliated firms occurs despite the stronger average performance of group firms relative to non-group firms prior to foreign bank entry. The average ROA of group firms in 1993 was $4.9 \%$ relative to $-0.9 \%$ for non-group firms. Groupaffiliated firms also exhibit a higher Tobin's Q on average relative to non-group firms during the 1990s. ${ }^{22}$ Hence, the decline in loans to group affiliated firms does not appear to arise because of an efficient reallocation of credit away from underperforming, politically-connected firms. Instead, the systematic drop in credit among these firms is suggestive that foreign bank competition adversely affects the ability of domestic banks to finance informationally-opaque firms.

One alternative hypothesis for the drop in overall bank credit to group-affiliated firms is that foreign banks only choose to finance the largest group member after entry, and these loans are then redistributed to other group firms. This could lead to a drop in overall likelihood of having a loan among group-affiliated firms, but an increase in the total bank loans of the entire group. However, in unreported regressions, the drop in the likelihood of receiving a loan is equally strong for group firms without another group member in the same district, and there is weak evidence to indicate a decrease in the overall amount of loans allocated to an entire group after foreign entry. Moreover, the decline in the likelihood of having a loan among group-affiliated firms is also equally strong for firms with group members located in districts containing India's largest cities versus those without. Therefore, the decline in domestic loans to these group-affiliated firms does not appear driven by a substitution away from local credit markets towards credit obtained by group members located in large cities.

22 These findings of stronger performance among group firms are consistent with Khanna and Palepu (2000), which finds that the benefits of group ownership structure in India often offsets the costs in terms of overall performance. 
In contrast, the non-group firms see a relative drop in the marginal importance of ROA for the likelihood of having an FI loan [column (3)] but an increase in the marginal importance of past profits in obtaining a bank loan [column (4)]. This is consistent with profitable, non-group firms dropping their relationships with domestic development banks and becoming clients of the new foreign banks. This is not true, however, of the group-affiliated firms. Not only are group-affiliated firms less likely to receive an FI loan following foreign bank entry, the relative importance of their past ROA is less with regards to their ability to obtain commercial bank loans [column (2)].

\section{V.B. Firm Performance and Profitability}

If competition from foreign banks induces a reallocation of loans away from informationally opaque borrowers, it is also possible the entry of a foreign bank could affect firm sales, profits, cash usage, and capital expenditures (CAPEX) of these firms. This will be particularly true among financially constrained firms that rely heavily on external financing. To test this, the sample is again divided between smaller and larger firms based on the total assets of firms in 1991. Firms in the bottom quartile are classified as 'small' and firms in the top quartile are 'large'. Smaller firms are most

likely to be financially constrained, and in Table X, it was shown that these firms experienced a larger drop in their loans following foreign entry. Therefore, if foreign bank entry reduces credit access to these firms, we would expect to observe a decline in their performance after entry relative to larger firms. To test this, the following equation is estimated:

$$
y_{i, j, d, t}=\beta_{0}+\beta_{1} \text { Foreign Bank }_{d, t}+\beta_{2}\left(\text { Foreign Bank }_{d, t} \times \mathrm{R} Z_{j}\right)+\alpha_{i}+\delta_{t}+\left(\delta_{t} \times R Z_{j}\right)+\varepsilon_{i, j, d, t}
$$

where $y$ is the performance measure of firm $i$, in industry $j$, district $d$, at time $t$. Similar to before, firm and year fixed effects are included. RZ is the industry-level measure of external finance dependency constructed by Rajan and Zingales (1998). A higher value indicates that U.S. firms of that industry rely more heavily on external financing for their investments. Inclusion of this variable interacted with the indicator for foreign bank entry will test for whether there is a differential change in the 
performance of firms that require more external financing after foreign bank entry.

Overall, the estimates reported in Table XII indicate that smaller firms, with greater external financing needs, exhibited a marked decline in performance following foreign bank entry in India, whereas there is no discernible impact on larger firms. As show in column (1), while there is no average drop in the growth of sales among smaller firms, there is a significant drop among smaller firms located in industries that require more external financing. Moreover, in columns (2)-(4), we see these same firms also exhibit a decline in profitability, capital expenditures, and cash reserves following foreign bank entry relative to small firms located elsewhere in India . These findings suggest that these smaller, external finance dependant firms were unable to substitute into alternative sources of financing following the decline in overall domestic bank credit and may have instead relied more heavily in internal cash to fund investments. In columns (5)-(8), however, we see that larger firms, even those located in industries requiring more external financing, do not experience a drop in performance. This may indicate their greater ability to tap alternative capital markets or the greater willingness of foreign lenders to finance these firms.

\section{Conclusion}

The entrance of new foreign banks to India is associated with a reallocation of loans that is not necessarily a boon to the lion's share of domestic firms. The most profitable ten percent of firms located near a new foreign bank branch received larger loans, but on average, firms were 7.6 percentage points less likely to have a long-term loan of any size following the entry of a foreign bank. This limited increase in loan sizes appears to arise from new foreign bank loans targeted primarily towards the most profitable firms. The decline in credit for all other firms, however, originates from a systematic drop in domestic bank loans. The findings are robust to using a number of different specifications, control variables, and instrumentation, and the timing of the loan reallocation coincides with foreign bank entry within each district. Moreover, the decline in domestic 
credit appears to be driven by shifts in the supply of loans rather than the demand for loans.

This reallocation of loans following foreign bank entry in India suggests that information asymmetries in the market for loans are a significant factor in LDCs. While credit access is improved for many very profitable firms, the extent and nature of the drop in loans to informationally opaque firms, as captured by a firms' size and group affiliation, suggests that some firms with positive net present value projects may have found it difficult to obtain loans after foreign bank entry.

Furthermore, the reduction in credit also appears to adversely affect the performance of smaller firms located in industries requiring greater external financing. Theory indicates this segmented credit market and adverse impact on some domestic firms' credit access and performance may occur when information asymmetries are large and domestic banks are ill-equipped to effectively screen potential clients. A larger decrease in the size of loans allocated to firms with fewer tangible assets after foreign bank entry indicates domestic lenders instead relied more heavily on collateralized loans after foreign entry rather than investing in new, costly screening technologies.

These findings have implications for financial policy in LDCs, which in recent years has increasingly trended towards the allowance of greater foreign bank entry. While the potential benefits of foreign bank entry are many, the evidence suggests that information asymmetries may prevent many firms in these economies from realizing these benefits. This finding parallels an existing literature that examines the comparative disadvantage of large banks in the production and use of 'soft' information (Berger, Miller, Petersen, Rajan, and Stein, 2005), and the unanticipated consequences that greater competition may have on the lending relationships that small and mediumsized entrepreneurs rely on (Boot and Thakor, 2000; Petersen and Rajan, 1995).

Overall, the empirical findings presented in this paper suggest that a proper sequencing of reforms in developing economies may be necessary to realize the benefits of foreign lender entry. Specifically, reducing information barriers and lowering domestic banks' cost of screening potential borrowers prior to foreign lenders' entry may improve the allocation of credit following liberalization 
and increase the range of firms foreign banks are willing to finance upon entry. For example, policymakers may consider strengthening accounting disclosure rules and promoting the development of credit evaluating agencies. By reducing banks' costs of obtaining information about firms, such policies may increase the range of firms foreign banks finance and reduce the scope for a systematic drop in loans from domestic banks in response to increased competition. 


\section{Appendix - Determining firm location within prowess}

The Prowess data set reports the district location of each firm's registered office, head office and registrar office. Nearly all firms (about 95\%) report the district location of their registered office, while only $25 \%$ report district location of their head office or registrar office. To determine a firm's location, the district of the registered office is used primarily. The registered office is the address each firm of more than 20 persons in India must submit to the Registrars of Companies (RoC) as dictated by the Companies Act, 1956. All communications and notices to the company are addressed to the registered office and is the official address of the company where statutory books and records must be kept. Every company must affix this address outside of every office or place at which activities of the company are carried out, and firms are required to file their balance sheet and annual return each year with the RoC. If the district location of the registered office is missing, however, the district location of the head office is used next, and the district location of the registrar address is used last. Only about two percent of firms are missing the district location of all three offices. 


\section{References}

Agenor, Pierre-Richard (2003) "Benefits and Costs of International Financial Integration: Theory and Facts," World Economy, 26(8), 1089-1118.

Barth, James R., Gerard Caprio Jr. and Ross Levine (2001) "The Regulation and Supervision of Banks around the World: A New Database," Brookings-Wharton Papers on Financial Services, pp. 183-240.

Bekaert, Geert and Campbell R. Harvey (2000) "Foreign Speculators and Emerging Equity Markets," Journal of Finance, 55(2), 565-613.

Bekaert, Geert, Campbell R. Harvey, and Christian Lundblad (2005) "Does Financial Liberalization Spur Growth?” Journal of Financial Economics, 77, 3-55.

Berger, Allen N., Leora F. Klapper and Gregory F. Udell (2001) “The ability of banks to lend to informationally opaque small businesses," Journal of Banking \& Finance, 25, 2127-2167.

Berger, Allen N., Nathan H. Miller, Mitchell A. Petersen, Raghuram G. Rajan, and Jeremy C. Stein (2005) "Does function follow organizational form? Evidence from lending practices of large and small banks," Journal of Financial Economics, 76, 237-269.

Berger, Philip G., Eli Ofek and Itzhak Swary (2001) "Investor Valuation and Abandonment Option," Journal of Financial Economics, 42, 257-287.

Bertrand, Marianne, Antoinette Schoar and David Thesmar (2007) "Banking Deregulation and Industry Structure: Evidence from the French Banking Reforms of 1985," Journal of Finance, 62(2), 597-628.

Besley, Timothy and Robin Burgess (2004), "Can Labor Regulation Hinder Economic Performance? Evidence from India,” Quarterly Journal of Economics, 119(1), 91-134.

Boot, Arnoud W.A. and Anjan V. Thakor (2000), "Can Relationship Banking Survive Competition?" Journal of Finance, 55(2), 679-713.

Brealey, R. A. and E. C. Kaplanis (1996) “The determination of foreign banking location,” Journal of International Money and Finance, 15(4), 577-597.

Cetorelli, Nicola and Philip E. Strahan (2006) "Finance as a Barrier to Entry: Bank Competition and Industry Structure in Local U.S. Markets," Journal of Finance, 61(1), 437-461.

Chari, Anusha and Peter Blair Henry (2004) "Risk Sharing and Asset Prices: Evidence from a Natural Experiment," Journal of Finance, 59(3), 1295-1324.

Cheng, Leonard K. and Yum K. Kwan (2000) "What are the determinants of the location of foreign direct investment? The Chinese experience," Journal of International Economics, 51, 379-400. 
Claessens, Stijn, Aslı Demirgüç-Kunt and Harry Huizinga (2001) "How does foreign entry affect domestic banking markets?” Journal of Banking \& Finance, 25, 891-911.

Clarke, George R. G., Robert Cull and Maria Soledad Martinez Peria (2006) "Foreign Bank Participation and Access to Credit Across Firms in Developing Countries," Journal of Comparative Economics, 34(4), 774-795.

Coughlin, Cletus C., Joseph V. Terza and Vachira Arromdee (1991) "State Characteristics and the Location of Foreign Direct Investment within the United States," Review of Economics and Statistics, 73(4), 675-683.

Dell'Ariccia, Giovanni and Robert Marquez (2004) “Information and bank credit allocation," Journal of Financial Economics, 72, 185-214.

Detragiache, Enrica, Poonam Gupta and Thierry Tressel (2007) "Foreign Banks in Poor Countries: Theory and Evidence," Journal of Finance, forthcoming.

Dutta, Sudipt (1997) Family Business in India, Response Books, Sage Publications, New Delhi.

Ghemawat, Pankaj and Tarun Khanna (1998) "The Nature of Diversified Business Groups: A Research Design and Two Case Studies," Journal of Industrial Economics, 46(1), 35-61.

Giannetti, Mariassunta and Steven Ongena (2007) "Financial Integration and Firm Performance: Evidence from Foreign Bank Entry in Emerging Markets," Review of Finance, forthcoming.

Gopalan, Radhakrishnan and Todd Gormley (2007) "The Going Public Decision and the Role of Public Equity Markets in Emerging Economies,” Washington University in St. Louis, working paper.

Gormley, Todd (2007) “Costly Information, Foreign Entry, and Credit Access," Washington University in St. Louis, working paper.

Greene, William (2004) "Fixed Effects and Bias Due to the Incidental Parameters Problem in the Tobit Model,” Econometric Reviews, 23(2), 125-147.

Haber, Stephen and Aldo Musacchio (2004) "Foreign Banks and the Mexican Economy, 1997-2004," working paper.

Hanson, James A. (2003) "Indian Banking: Market Liberalization and the Pressures for Institutional and Market Framework Reform" in Anne O. Krueger and Sajjid Z. Chinoy eds., Reforming India's External, Financial, and Fiscal Policies, Stanford University Press, California, 97-126.

Henry, Peter Blair (2000a) "Stock Market Liberalization, Economic Reform, and Emerging Equity Prices," Journal of Finance, 55(2), 529-564.

(2000b) “Do Stock Market Liberalizations Cause Investment Booms?” Journal of Financial Economics, 58, 301-334.

Hines, James R. (1996) "Altered States: Taxes and the Location of Foreign Direct Investment in America," American Economic Review, 86(5), 1076-1094. 
Khanna, Tarun and Krishna Palepu (1999) "Emerging Market Business Groups, Foreign Investors, and Corporate Governance," National Bureau of Economic Research, working paper, 6955.

Khanna, Tarun and Krishna Palepu (2000) "Is Group Affiliation Profitable in Emerging Markets? An Analysis of Diversified Business Groups," Journal of Finance, 55(2), 867-891.

Lensink, R. and Niels Hermes (2004) "The short-term effects of foreign bank entry on domestic bank behaviour: Does economic development matter?” Journal of Banking \& Finance, 28, 553-568

Levine, Ross (1996) “Foreign Banks, Financial Development, and Economic Growth," in Claude E. Barfield ed., International Financial Markets: Harmonization versus Competition, AEI Press, Washington, DC, 224-254.

Mian, Atif (2006) "Distance Constraints: The Limits of Foreign Lending in Poor Economies," Journal of Finance, 61(3), 1465-1505.

Petersen, Mitchell A. and Raghuram G. Rajan (1995) "The Effect of Credit Market Competition on Lending Relationships," Quarterly Journal of Economics, 110(2), 407-443.

(2002) "Does Distance Still Matter? The Information Revolution in Small Business Lending," Journal of Finance, 57(6), 2533-2570.

Rajan, Raghuram G. and Luigi Zingales (1998) "Financial Dependence and Growth," American Economic Review, 88(3), 559-586.

Reserve Bank of India “Directory of Bank Offices in India (2003-2004),” Mumbai, India.

Sabi, Manijeh (1988) "An Application of the Theory of Foreign Direct Investment to Multinational Banking in LLDCs," Journal of International Business Studies, 19(3), 433-447.

Sengupta, Rajdeep (2007) "Foreign Entry and Bank Competition," Journal of Financial Economics, 84(2), pp. 502-528.

Tannan, M.L. and C.R. Datta (1998) Tannan's Banking Law and Practice in India, 19th Edition, India Law House, New Delhi.

Tarapore, S.S. (1999) "Indian Banking: Preparing for the Next Round of Reform," in James A. Hanson and Sanjay Kathuria eds., India: A Financial Sector for the Twenty First Century, Oxford University Press, New Delhi, 57-131.

Yamori, Nobuyoshi (1998) "A note on the location choice of multinational banks: The case of Japanese financial institutions," Journal of Banking \& Finance, 22, 109-120.

Zarutskie, Rebecca (2006) "Evidence on the Effects of Bank Competition on Firm Borrowing and Investment," Journal of Financial Economics, 81(3), 503-537. 


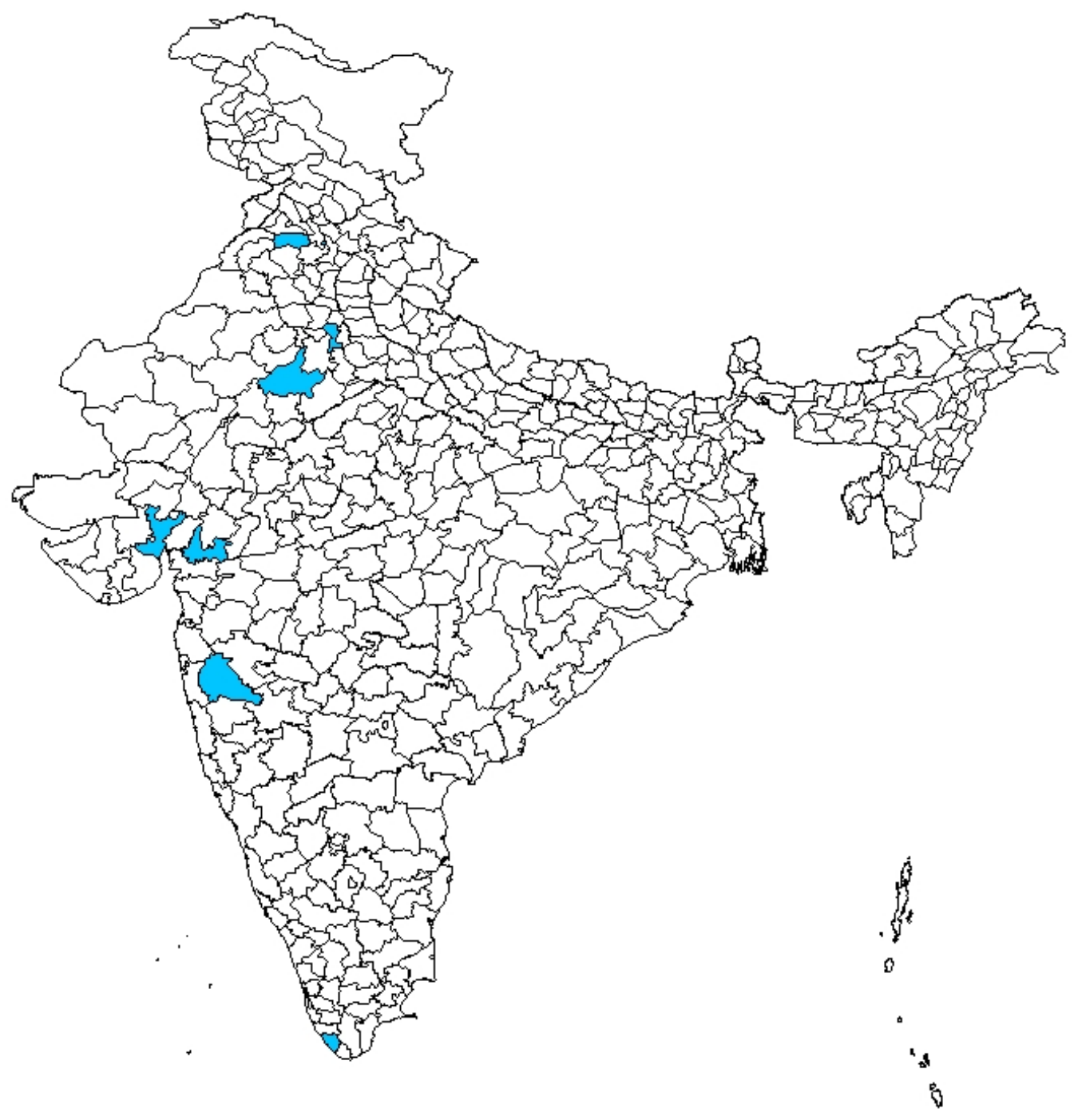

Figure 1 - Indian Districts with First Foreign Bank Entry between 1991-2002 


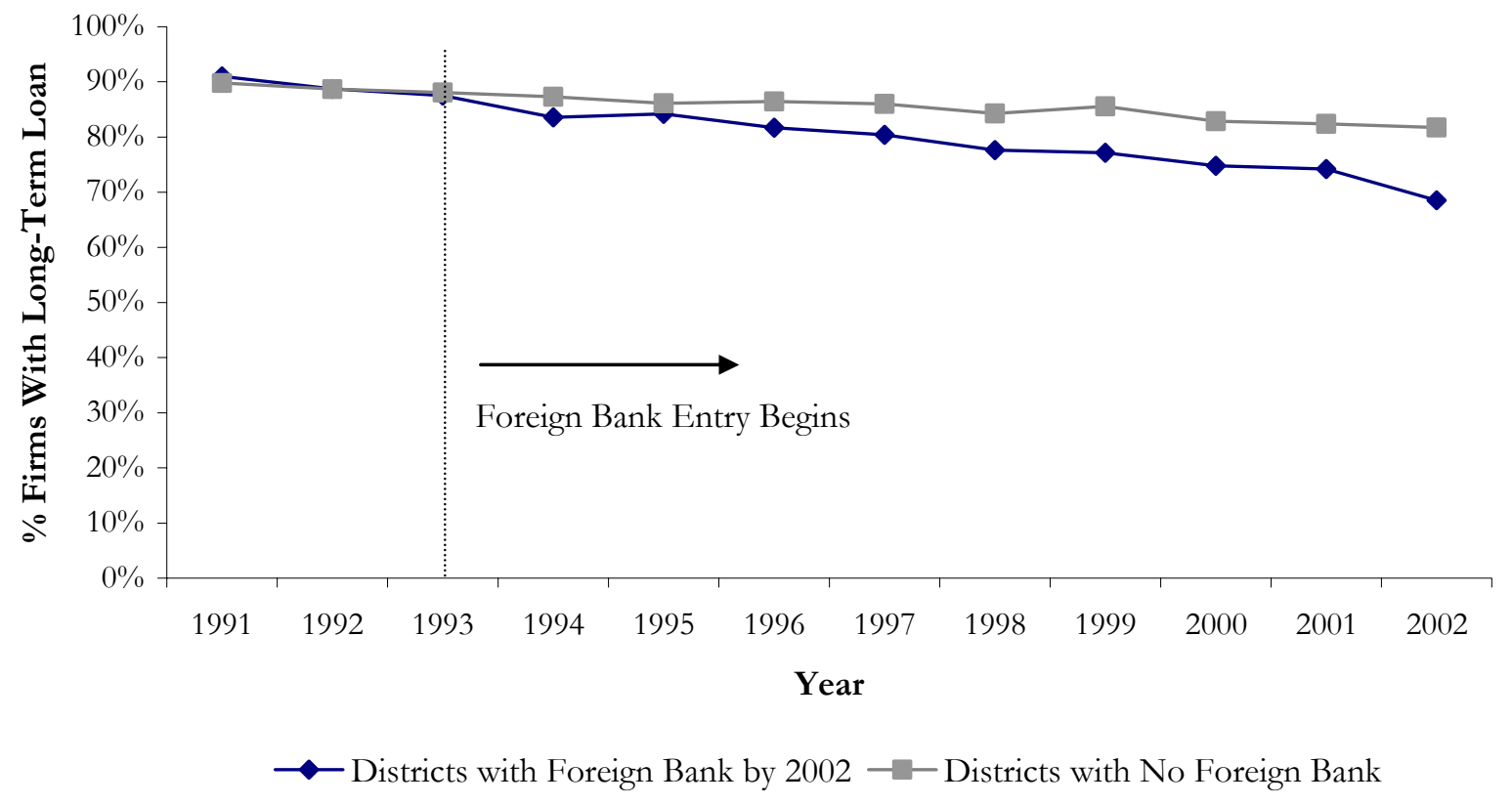

Figure 2. Event Study Graph of Foreign Bank Entry, 1991-2002. 'Districts with a Foreign Bank by 2002' represents all firms located in districts that receive their first foreign bank between 1991-2002, and 'Districts with No Foreign Bank' represents all firms located in districts without a foreign bank by 2002. The percent of firms with a long-term loan in each type of district is calculated using domestic, non-financial firms with positive sales and assets in 1991. 


\section{A. Firms with $R O A>$ 90th Percentile}

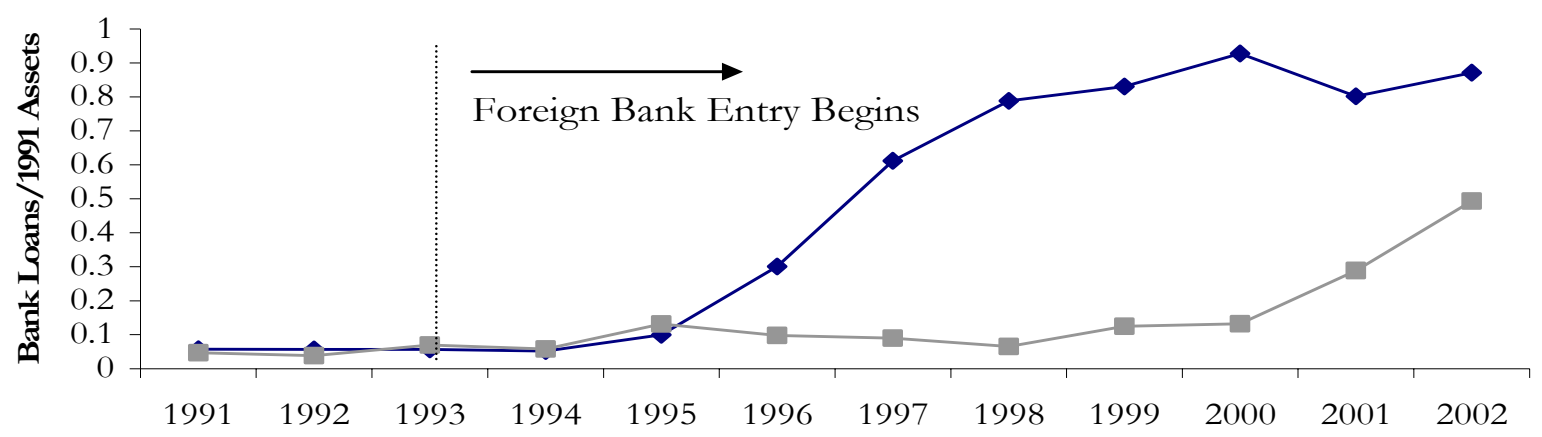

3B. Firms with Median $<$ ROA $<=90$ th Percentile

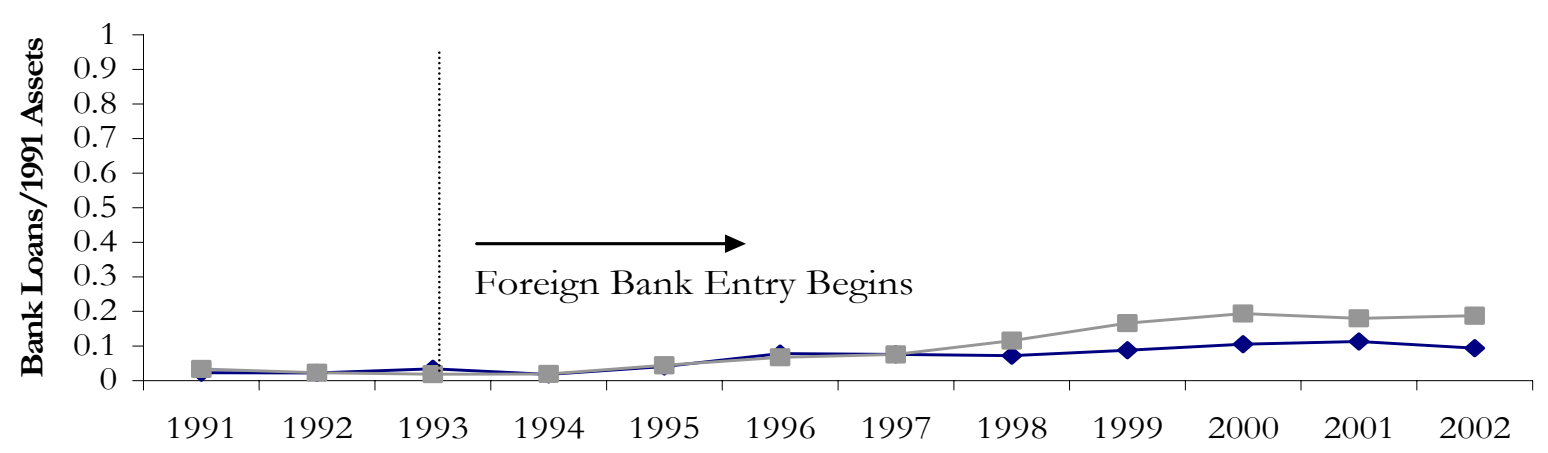

3C. Firms with $R O A<=$ Median

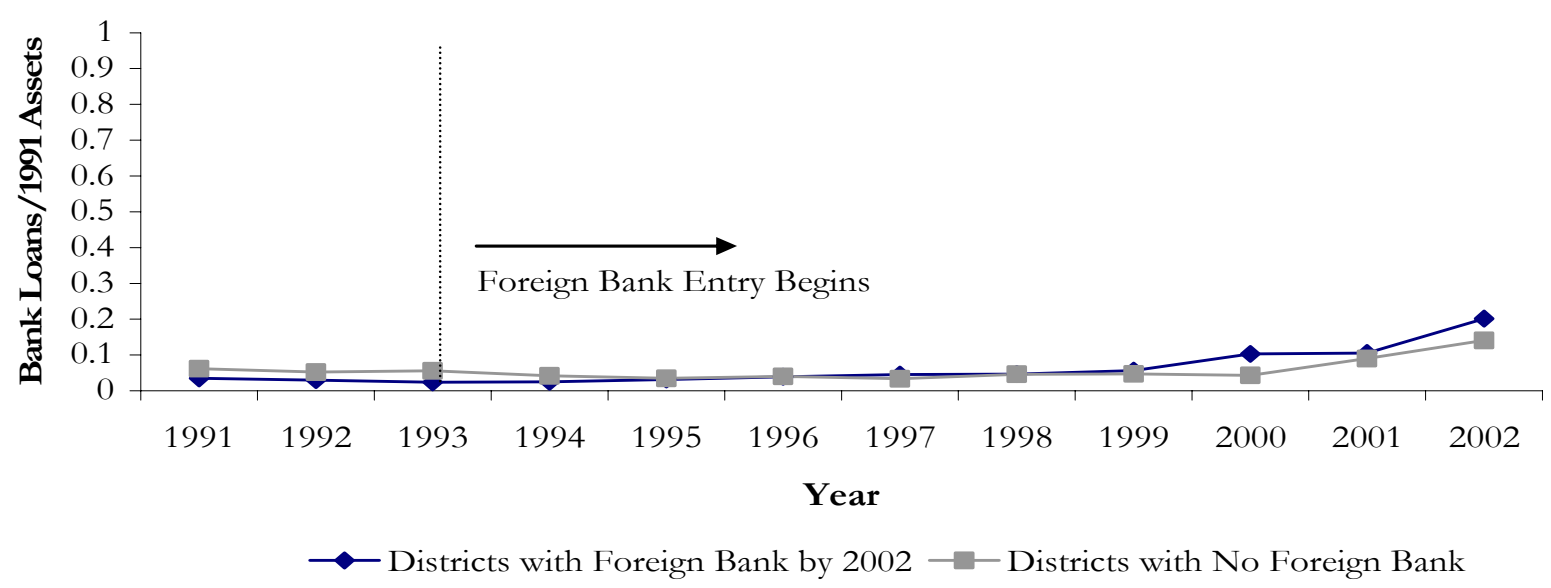

Figure 3. Average Bank Loans over 1991 Assets by ROA. 'Districts with a Foreign Bank by 2002' represents firms located in districts that receive their first foreign bank between 1991-2002, and 'Districts with No Foreign Bank' represents firms located in districts without a foreign bank by 2002. Each line represents the average bank loans / 1991 assets of firms with positive sales and assets in 1991 where ROA is the average return on assets of firms from 1991-1993. 
4A. Timing of Increase in Bank Loans for Firms with $R O A>$ 90th Percentile

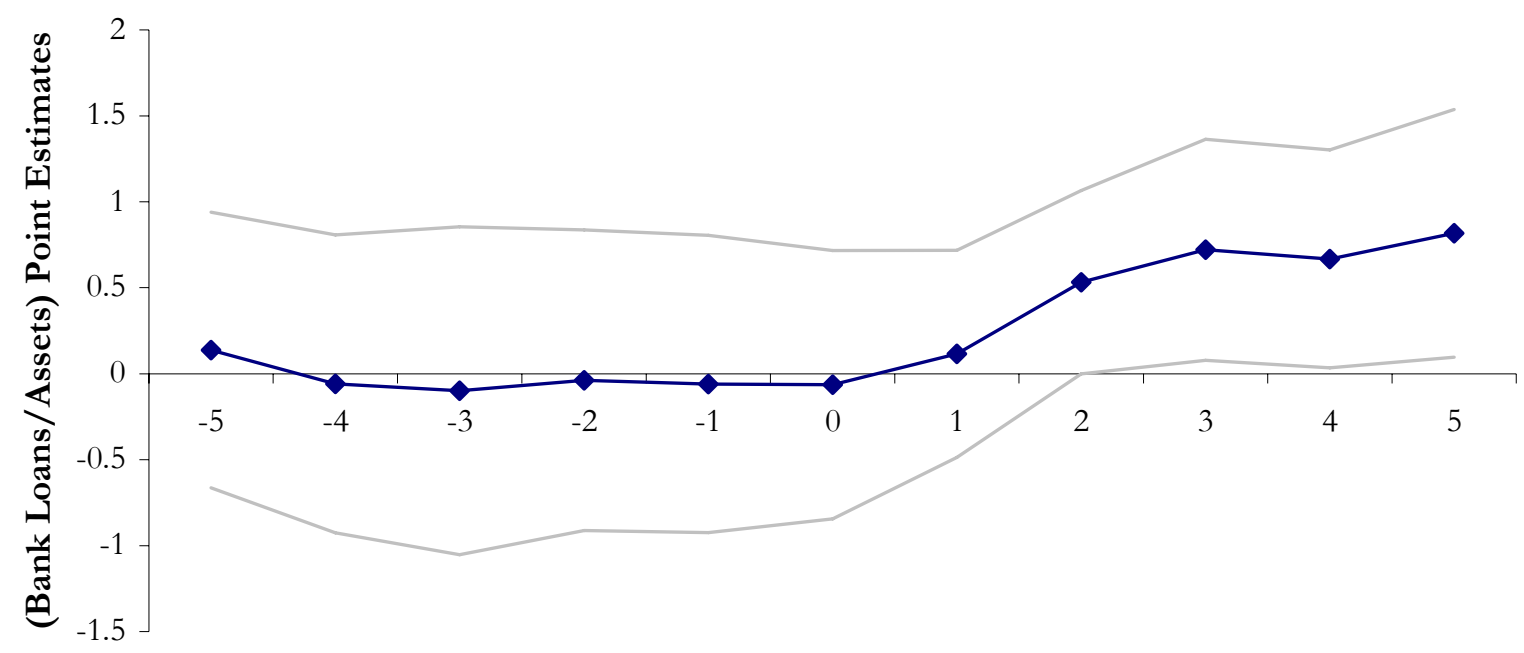

4B. Timing of Decrease in FI Loans for All Firms

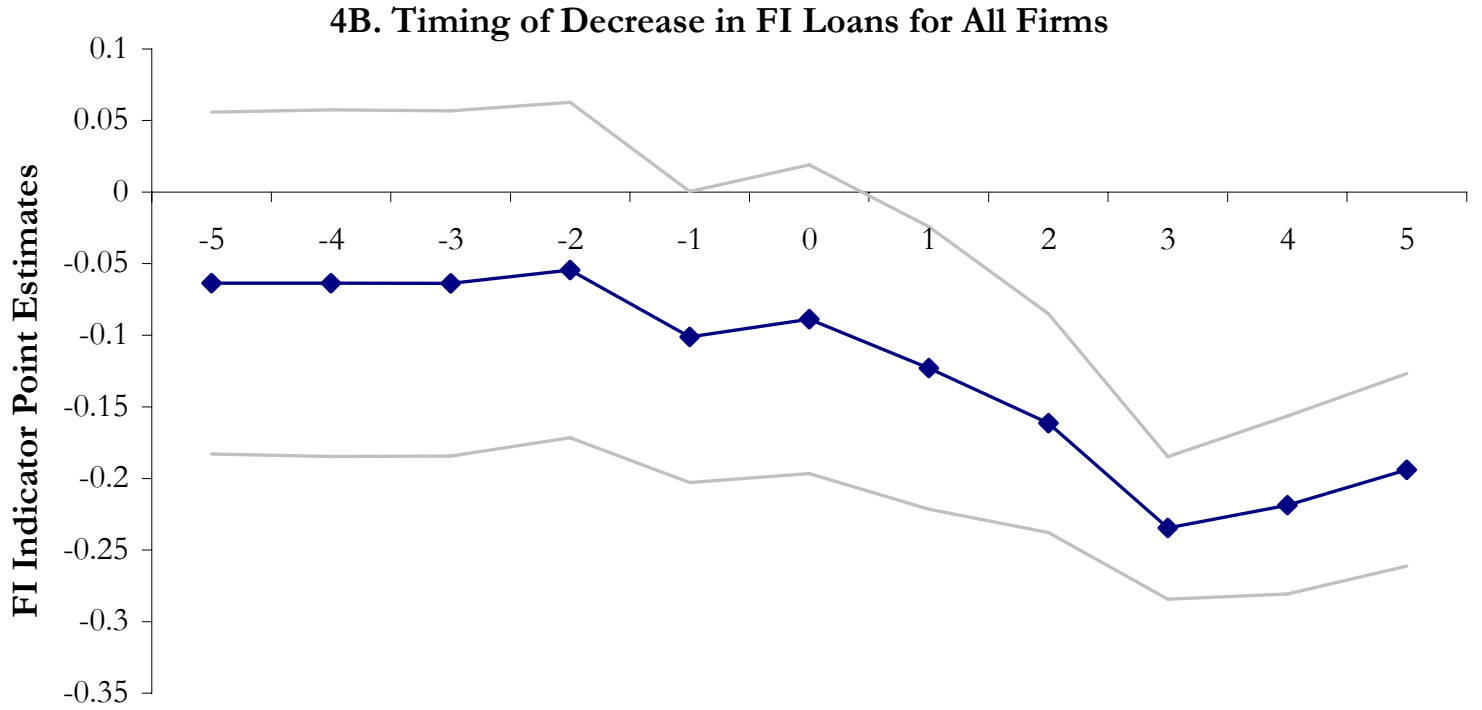

Year Pertaining to Actual Foreign Bank Entry

Figure 4. Timing of Changes in Loan Allocation. This figure plots point estimates from fully saturated OLS regressions of loan measures onto indicators for years pertaining to actual foreign bank entry. The regressions include firm and year dummies and use yearly observations from 1991 to 2002 for firms with positive assets and sales in 1991 but not located in a district with a foreign bank by 1991. In Panel A, the dependent variable is bank loans / 1991 assets, and the regression is restricted to firms with an ROA above the $90^{\text {th }}$ percentile, where ROA is the average return on assets return on assets of firms from 1991-1993. In Panel B, the dependent variable is FI Loan Indicator, and all firms are included. While both regressions are fully saturated, only point estimates for five years preceding and following foreign entry are plotted. The standard errors were clustered at the district level, and the 95th percentile confidence intervals are shown. 


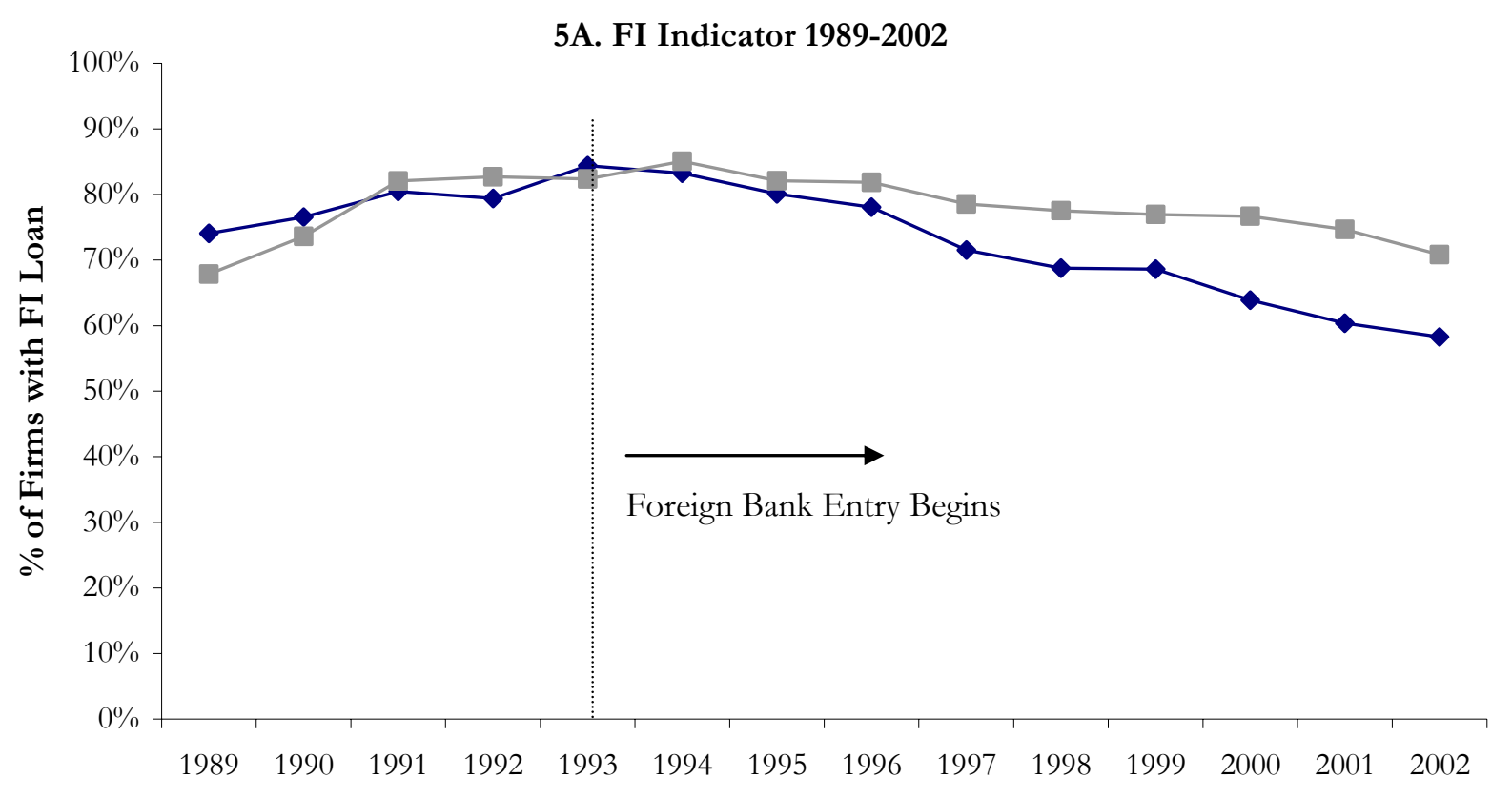

5B. Bank Loans 1989-2002

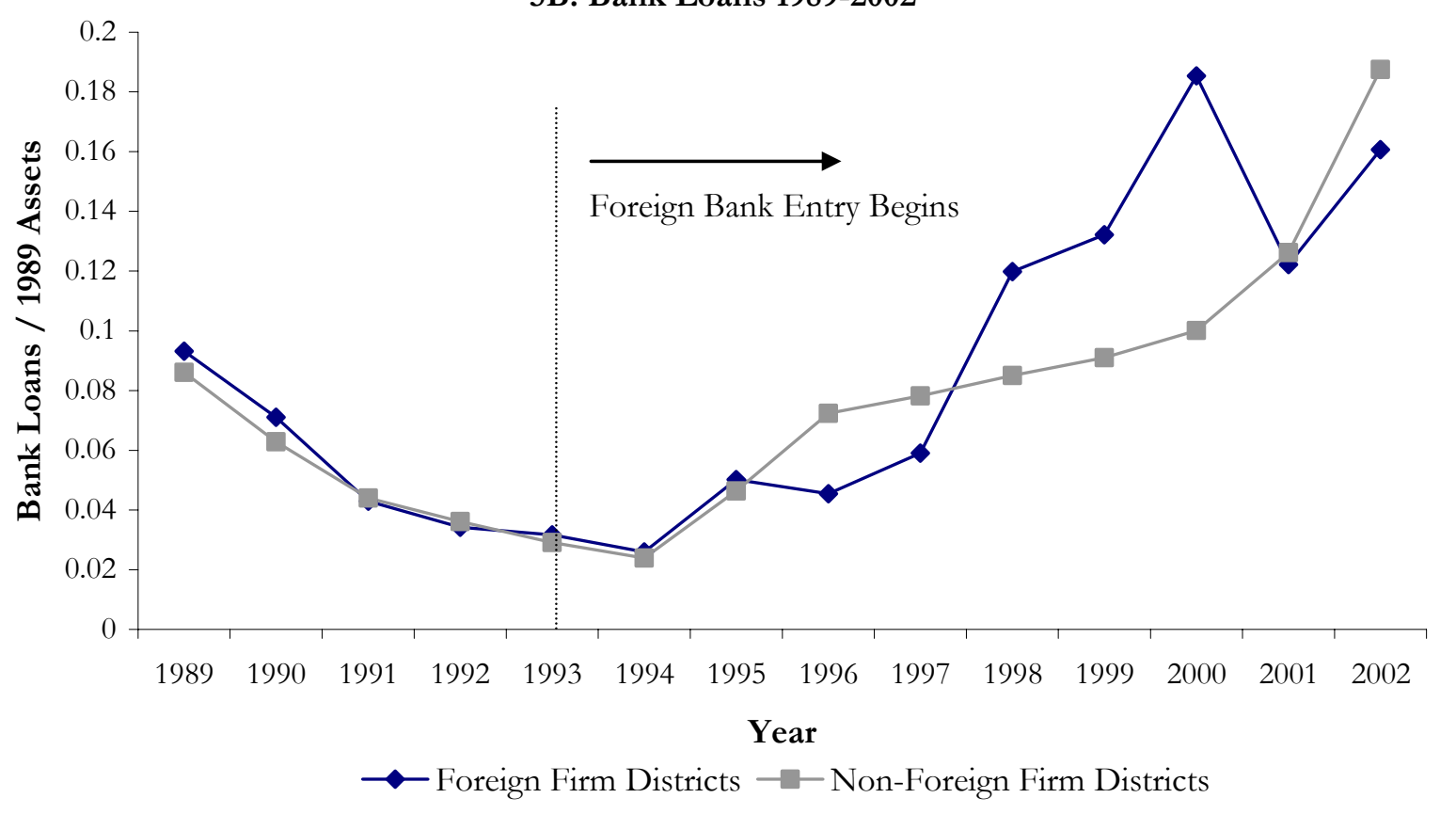

Figure 5. Falsification Tests of Instrument. 'Foreign Firm Districts' represents firms located in districts with a foreign firm present in 1993, and 'Non-Foreign Firm Districts' represents firms located in districts without a foreign firm in 1993. Averages are calculated using domestic, nonfinancial firms with positive sales and assets in 1989. 
Table I

Number of Foreign Bank Branches in India by District and Year

Number of foreign bank branches calculated using the Directory of Bank Offices. Bank numbers represent total branches as of March 31 for each year.

\begin{tabular}{|c|c|c|c|c|c|c|c|c|c|c|c|c|c|c|}
\hline District Name & State Name & 1990 & 1991 & 1992 & 1993 & 1994 & 1995 & 1996 & 1997 & 1998 & 1999 & 2000 & 2001 & 2002 \\
\hline \multicolumn{15}{|c|}{ Districts with Pre-Existing Foreign Bank Branches } \\
\hline Amritsar & Punjab & 3 & 3 & 3 & 3 & 3 & 3 & 3 & 3 & 3 & 2 & 1 & 1 & 1 \\
\hline Bangalore Urban & Kanrataka & 2 & 2 & 2 & 3 & 3 & 5 & 6 & 7 & 7 & 10 & 11 & 11 & 12 \\
\hline Coimbatore & Tamil Nadu & 1 & 1 & 1 & 1 & 1 & 1 & 1 & 1 & 2 & 2 & 2 & 3 & 4 \\
\hline Darjiling & West Bengal & 1 & 1 & 1 & 1 & 1 & 1 & 1 & 1 & 1 & 1 & 1 & 1 & 1 \\
\hline Delhi & Delhi & 22 & 23 & 24 & 24 & 26 & 28 & 28 & 31 & 35 & 36 & 37 & 38 & 37 \\
\hline Ernakulam & Kerala & 3 & 3 & 3 & 3 & 4 & 4 & 4 & 4 & 4 & 3 & 3 & 3 & 4 \\
\hline Greater Mumbai & Maharashtra & 51 & 52 & 52 & 51 & 51 & 55 & 58 & 63 & 65 & 63 & 64 & 64 & 63 \\
\hline Haora & West Bengal & 2 & 2 & 2 & 2 & 2 & 2 & 2 & 2 & 2 & 2 & 2 & 2 & 2 \\
\hline Hyderabad & Andhra Pradesh & 1 & 1 & 1 & 1 & 1 & 2 & 2 & 2 & 2 & 4 & 6 & 8 & 8 \\
\hline Kamrup & Assam & 1 & 1 & 1 & 1 & 1 & 1 & 1 & 1 & 1 & 1 & 1 & 1 & 1 \\
\hline Kanpur City & Uttar Pradesh & 3 & 3 & 3 & 3 & 3 & 3 & 3 & 3 & 3 & 3 & 3 & 3 & 3 \\
\hline Kolkata & West Bengal & 43 & 43 & 42 & 42 & 42 & 42 & 42 & 43 & 43 & 34 & 34 & 34 & 34 \\
\hline Kozhikode & Kerala & 1 & 1 & 1 & 1 & 1 & 1 & 1 & 1 & 1 & 1 & & & \\
\hline Chennai & Tamil Nadu & 11 & 11 & 11 & 12 & 12 & 12 & 14 & 15 & 16 & 16 & 16 & 16 & 16 \\
\hline Simla & Himachal Pradesh & 1 & 1 & 1 & 1 & 1 & 1 & 1 & 1 & 1 & 1 & 1 & 1 & 1 \\
\hline South Goa & Goa & 1 & 1 & 1 & 1 & 1 & 1 & 1 & 1 & 1 & 1 & & & \\
\hline Srinagar & Jammu \& Kashmir & 1 & 1 & 1 & 1 & 1 & 1 & 1 & 1 & 1 & 1 & 1 & 1 & 1 \\
\hline Vishakhapatnam & Andhra Pradesh & 1 & 1 & 1 & 1 & 1 & 1 & 1 & 1 & 1 & 1 & 1 & 1 & 1 \\
\hline \multicolumn{15}{|c|}{ Districts Receiving First Foreign Bank } \\
\hline Thiruvananthapuram & Kerala & & & & & 1 & 1 & 1 & 1 & 1 & 1 & 1 & 1 & 1 \\
\hline Ahmedabad & Gujarat & & & & & & 2 & 2 & 3 & 3 & 5 & 5 & 8 & 8 \\
\hline Pune & Maharashtra & & & & & & & 1 & 1 & 4 & 5 & 5 & 5 & 6 \\
\hline Chandigarh & Chandigarh & & & & & & & & 1 & 1 & 1 & 1 & 2 & 2 \\
\hline Gurgaon & Haryana & & & & & & & & & & 1 & 1 & 1 & 2 \\
\hline Vadodara & Gujarat & & & & & & & & & & 1 & 1 & 2 & 2 \\
\hline Jaipur & Rajasthan & & & & & & & & & & & & 1 & 1 \\
\hline Ludhiana & Punjab & & & & & & & & & & & & 1 & 1 \\
\hline$\overline{\text { Total Foreign Bank }}$ & anches & 149 & 151 & 151 & 152 & 156 & 167 & 174 & 187 & 198 & 196 & 198 & 209 & 212 \\
\hline
\end{tabular}


Table II

\section{Summary Statistics by Type of District, Using 1993 Data}

Summary statistics are presented by the degree of district-level foreign bank presence. Statistics for districts with a foreign bank by 1991 are presented in column (1) while statistics for districts with no foreign bank in 1991 but with a foreign bank by 2002 are reported in column (2), and statistics for districts still without a foreign bank by 2002 are presented in column (3). Firm statistics are un-weighted averages calculated using 1993 Prowess data for all domestic, non-financial firms with positive sales and assets in 1991. Population and district area data are obtained from the 1991 Census and the Directory of Bank Offices. District level characteristics are calculated using un-weighted means.

\begin{tabular}{|c|c|c|c|}
\hline & \multirow{2}{*}{$\begin{array}{l}\text { Districts with } \\
\text { Pre-Existing } \\
\text { Foreign Banks }\end{array}$} & \multicolumn{2}{|c|}{ Districts with No Foreign Bank in 1991} \\
\hline & & $\begin{array}{l}\text { Foreign Bank by } \\
\qquad 2002\end{array}$ & $\begin{array}{c}\text { No Foreign } \\
\text { Bank by } 2002\end{array}$ \\
\hline & $(1)$ & (2) & (3) \\
\hline \multicolumn{4}{|l|}{ Firm Characteristics } \\
\hline Total Assets (10 mn. Rp.) & 511.78 & 229.21 & 259.12 \\
\hline 1991-1993 Average ROA (\%) & 2.48 & 3.75 & 2.07 \\
\hline Short-Term Bank Credit / Total Borrowings & 0.380 & 0.344 & 0.350 \\
\hline Long-Term Bank \& FI Loans / Total Borrowings & 0.298 & 0.337 & 0.373 \\
\hline Short-Term Bank Credit / Assets & 0.148 & 0.123 & 0.148 \\
\hline Long-Term Bank Loans / Assets & 0.041 & 0.023 & 0.034 \\
\hline FI Loans / Assets & 0.106 & 0.118 & 0.168 \\
\hline$\%$ of Firms with Long-Term Loan & 80.2 & 87.5 & 88.1 \\
\hline \% Firms with Bank Loan & 42.2 & 43.1 & 44.1 \\
\hline \% Firms with FI Loan & 69.3 & 80.6 & 81.4 \\
\hline \multicolumn{4}{|l|}{ District Banking \& Population Characteristics } \\
\hline Population / Km2 & 6591 & 1228 & 476 \\
\hline Total Banks / Million People & 135 & 118 & 72 \\
\hline$\%$ Share of Private Banks & 11.32 & 6.13 & 6.13 \\
\hline Number of Districts & 14 & 8 & 154 \\
\hline Number of Firms & 1047 & 156 & 500 \\
\hline
\end{tabular}




\section{Table III \\ Effect of Foreign Bank Entry on Total Long-Term Loans}

This table reports coefficients from regressions of total long-term loans onto district and firm characteristics using OLS with firm and year fixed effects. The dependent variable is an indicator for having a long-term loan in columns (1)-(4) and the stock long-term loans normalized by 1991 assets in columns (5)-(8). Yearly observations from 1991 to 2002 are included for domestic, non-financial firms with positive sales and assets in 1991 but not located in a district with a foreign bank by 1991. 'Foreign Bank' is equal to one for firms located in a district with a foreign bank in the given year, and zero otherwise. 'ROA' is a firm's 1991-1993 average percent return on assets, demeaned. Columns (3) \& (7) include 4-digit industry-year interactions. Columns (4) \& (8) restrict the sample to 'treated' firms located in districts with a foreign bank by 2004 . Standard errors, clustered at the district-level, are reported in parentheses. $*=10 \%$ level, $* *=5 \%$ level, $* * *=1 \%$ level.

\begin{tabular}{|c|c|c|c|c|c|c|c|c|}
\hline \multirow[t]{2}{*}{ Dependent Variable $=$} & \multicolumn{4}{|c|}{ Indicator for Long-Term Loan } & \multicolumn{4}{|c|}{ Long-Term Loans / 1991 Assets } \\
\hline & (1) & (2) & (3) & (4) & $(5)$ & (6) & (7) & $(8)$ \\
\hline Foreign Bank & $\begin{array}{c}-0.076 * * * \\
(0.027)\end{array}$ & $\begin{array}{c}-0.075^{* * *} \\
(0.028)\end{array}$ & $\begin{array}{c}-0.080^{* * *} \\
(0.028)\end{array}$ & $\begin{array}{c}-0.077 * * \\
(0.032)\end{array}$ & $\begin{array}{l}-0.049 \\
(0.150)\end{array}$ & $\begin{array}{l}-0.078 \\
(0.141)\end{array}$ & $\begin{array}{l}-0.181 \\
(0.249)\end{array}$ & $\begin{array}{l}-0.046 \\
(0.106)\end{array}$ \\
\hline Foreign Bank $*$ ROA & & $\begin{array}{c}-0.003 * \\
(0.002)\end{array}$ & $\begin{array}{l}-0.003 \\
(0.002)\end{array}$ & $\begin{array}{l}-0.002 \\
(0.002)\end{array}$ & & $\begin{array}{l}0.011^{*} \\
(0.006)\end{array}$ & $\begin{array}{c}0.011 \\
(0.006)\end{array}$ & $\begin{array}{c}0.019 * * * \\
(0.005)\end{array}$ \\
\hline Observations & 7088 & 7088 & 7088 & 2617 & 7088 & 7088 & 7088 & 2617 \\
\hline R-squared & 0.55 & 0.56 & 0.67 & 0.56 & 0.50 & 0.51 & 0.61 & 0.56 \\
\hline Number of Districts & 162 & 162 & 162 & 17 & 162 & 162 & 162 & 17 \\
\hline ROA-Year Interactions & & $\mathrm{X}$ & $\mathrm{X}$ & $\mathrm{X}$ & & $\mathrm{X}$ & $\mathrm{X}$ & $\mathrm{X}$ \\
\hline 4-Digit Industry-Year Interactions & & & $\mathrm{X}$ & & & & $\mathrm{X}$ & \\
\hline "Treated" Control Group Used & & & & $\mathrm{X}$ & & & & $\mathrm{X}$ \\
\hline
\end{tabular}




\section{Table IV}

\section{Access to Bank and FI Loans}

This table reports coefficients from separate regressions of bank and FI loan indicators onto district and firm characteristics using OLS with firm and year fixed effects. The dependent variable is an indicator for having a bank loan in columns (1)-(4) and an indicator for FI loans in columns (5)(8). Yearly observations from 1991 to 2002 are included for domestic, non-financial firms with positive sales and assets in 1991 but not located in a district with a foreign bank by 1991. 'Foreign Bank' is equal to one for firms located in a district with a foreign bank in the given year, and zero otherwise. 'ROA' is a firm's 1991-1993 average percent return on assets, demeaned. Columns (3) \& (7) include 4-digit industry-year interactions. Columns (4) \& (8) restrict the sample to 'treated' firms located in districts with a foreign bank by 2004. Standard errors, clustered at the district-level, are reported in parentheses. $*=10 \%$ level, $* *=5 \%$ level, $* * *=1 \%$ level.

\begin{tabular}{|c|c|c|c|c|c|c|c|c|}
\hline \multirow[t]{2}{*}{ Dependent Variable = } & \multicolumn{4}{|c|}{ Indicator for Bank Loan } & \multicolumn{4}{|c|}{ Indicator for FI Loan } \\
\hline & $(1)$ & (2) & (3) & (4) & (5) & (6) & (7) & (8) \\
\hline Foreign Bank & $\begin{array}{c}0.008 \\
(0.038)\end{array}$ & $\begin{array}{c}0.009 \\
(0.039)\end{array}$ & $\begin{array}{l}-0.014 \\
(0.035)\end{array}$ & $\begin{array}{c}0.038 \\
(0.038)\end{array}$ & $\begin{array}{c}-0.084^{* *} \\
(0.040)\end{array}$ & $\begin{array}{c}-0.087 * * \\
(0.039)\end{array}$ & $\begin{array}{l}-0.065^{*} \\
(0.037)\end{array}$ & $\begin{array}{c}-0.073^{* *} \\
(0.035)\end{array}$ \\
\hline Foreign Bank * ROA & & $\begin{array}{l}-0.003 * \\
(0.002)\end{array}$ & $\begin{array}{l}-0.002 \\
(0.002)\end{array}$ & $\begin{array}{l}-0.003 \\
(0.002)\end{array}$ & & $\begin{array}{l}-0.001 \\
(0.001)\end{array}$ & $\begin{array}{c}0.000 \\
(0.002)\end{array}$ & $\begin{array}{l}-0.001 \\
(0.001)\end{array}$ \\
\hline Observations & 7088 & 7088 & 7088 & 2617 & 7088 & 7088 & 7088 & 2617 \\
\hline R-squared & 0.46 & 0.47 & 0.56 & 0.45 & 0.64 & 0.65 & 0.72 & 0.65 \\
\hline Number of Districts & 162 & 162 & 162 & 17 & 162 & 162 & 162 & 17 \\
\hline $\begin{array}{l}\text { ROA-Year Interactions } \\
\text { 4-Digit Industry-Year Interactions }\end{array}$ & & $\mathrm{X}$ & $\begin{array}{l}X \\
X\end{array}$ & $\mathrm{X}$ & & $\mathrm{X}$ & $\begin{array}{l}X \\
X\end{array}$ & $\mathrm{X}$ \\
\hline "Treated" Control Group Used & & & & $\mathrm{X}$ & & & & $\mathrm{X}$ \\
\hline
\end{tabular}


Table V

\section{Size of Bank and FI Loans}

This table reports coefficients from regressions of bank and FI loan sizes onto district and firm characteristics using OLS with firm and year fixed effects. The dependent variable is the stock of bank loans normalized by 1991 assets in columns (1)-(4) and the stock of FI loans normalized by assets in columns (5)-(8). Yearly observations from 1991 to 2002 are included for domestic, non-financial firms with positive sales and assets in 1991 but not located in a district with a foreign bank by 1991. 'Foreign Bank' is equal to one for firms located in a district with a foreign bank in the given year, and zero otherwise. 'ROA' is a firm's 1991-1993 average percent return on assets, demeaned. Columns (3) \& (7) include 4-digit industry-year interactions. Columns (4) \& (8) restrict the sample to 'treated' firms located in districts with a foreign bank by 2004. Standard errors, clustered at the district-level, are reported in parentheses. $*=10 \%$ level, $* *=5 \%$ level, $* * *=1 \%$ level.

\begin{tabular}{|c|c|c|c|c|c|c|c|c|}
\hline \multirow[t]{2}{*}{ Dependent Variable = } & \multicolumn{4}{|c|}{ Bank Loans / 1991 Assets } & \multicolumn{4}{|c|}{ FI Loans / 1991 Assets } \\
\hline & $(1)$ & $(2)$ & (3) & (4) & $(5)$ & $(6)$ & (7) & $(8)$ \\
\hline Foreign Bank & $\begin{array}{c}0.041 \\
(0.069)\end{array}$ & $\begin{array}{c}0.029 \\
(0.063)\end{array}$ & $\begin{array}{c}0.030 \\
(0.070)\end{array}$ & $\begin{array}{c}0.035 \\
(0.046)\end{array}$ & $\begin{array}{l}-0.089 \\
(0.093)\end{array}$ & $\begin{array}{l}-0.108 \\
(0.090)\end{array}$ & $\begin{array}{l}-0.211 \\
(0.202)\end{array}$ & $\begin{array}{l}-0.081 \\
(0.081)\end{array}$ \\
\hline Foreign Bank * ROA & & $\begin{array}{c}0.006 * * \\
(0.002)\end{array}$ & $\begin{array}{c}0.007 * * * \\
(0.003)\end{array}$ & $\begin{array}{c}0.007 * * * \\
(0.002)\end{array}$ & & $\begin{array}{c}0.005 \\
(0.006)\end{array}$ & $\begin{array}{c}0.004 \\
(0.007)\end{array}$ & $\begin{array}{c}0.012^{* * *} \\
(0.004)\end{array}$ \\
\hline Observations & 7088 & 7088 & 7088 & 2617 & 7088 & 7088 & 7088 & 2617 \\
\hline R-squared & 0.42 & 0.43 & 0.51 & 0.53 & 0.50 & 0.50 & 0.61 & 0.54 \\
\hline Number of Districts & 162 & 162 & 162 & 17 & 162 & 162 & 162 & 17 \\
\hline $\begin{array}{l}\text { ROA-Year Interactions } \\
\text { 4-Digit Industry-Year Interactions } \\
\text { "Treated" Control Group Used }\end{array}$ & & $\mathrm{X}$ & $\begin{array}{l}X \\
X\end{array}$ & $\mathrm{X}$ & & $\mathrm{X}$ & $\begin{array}{l}X \\
X\end{array}$ & $\mathrm{X}$ \\
\hline
\end{tabular}




\section{Table VI}

\section{Scope of Foreign Bank Entry Effect on Size of Bank Loans}

This table reports coefficients from regressions of bank loans normalized by 1991 assets onto district and firm characteristics using OLS with firm and year fixed effects and ROA-Year Interactions. Yearly observations from 1991 to 2002 are included for domestic, non-financial firms with positive sales and assets in 1991 but not located in a district with a foreign bank by 1991. Columns (1)-(3) drop firms with 'ROA' exceeding the 90th percentile, and columns (4)-(6) drop firms with assets in 1991 exceeding the median.

'Foreign Bank' is equal to one for firms located in a district with a foreign bank in the given year, and zero otherwise. 'ROA' is a firm's 1991-1993 average percent return on assets, demeaned. Columns (2) \& (5) include 4-digit industry-year interactions. Columns (3) \& (6) restrict the sample to 'treated' firms located in districts with a foreign bank by 2004. Standard errors, clustered at the district-level, are reported in parentheses. $*=10 \%$ level, $* *=5 \%$ level, $* * *=1 \%$ level.

\begin{tabular}{|c|c|c|c|c|c|c|}
\hline \multirow{3}{*}{ Firms Dropped = } & \multicolumn{6}{|c|}{ Dependent Variable = Bank Loans $/ 1991$ Assets } \\
\hline & \multicolumn{3}{|c|}{ ROA $>90$ th Percentile } & \multicolumn{3}{|c|}{1991 Assets $>$ 50th Percentile } \\
\hline & $(1)$ & $(2)$ & (3) & $(4)$ & $(5)$ & $(6)$ \\
\hline Foreign Bank & $\begin{array}{l}-0.012 \\
(0.029)\end{array}$ & $\begin{array}{c}0.008 \\
(0.024)\end{array}$ & $\begin{array}{c}0.005 \\
(0.020)\end{array}$ & $\begin{array}{l}-0.026 \\
(0.061)\end{array}$ & $\begin{array}{l}-0.081 \\
(0.074)\end{array}$ & $\begin{array}{l}-0.010 \\
(0.049)\end{array}$ \\
\hline Foreign Bank * ROA & $\begin{array}{l}-0.001 \\
(0.001)\end{array}$ & $\begin{array}{l}-0.001 \\
(0.001)\end{array}$ & $\begin{array}{c}0.000 \\
(0.001)\end{array}$ & $\begin{array}{l}-0.002 \\
(0.002)\end{array}$ & $\begin{array}{l}-0.006 \\
(0.004)\end{array}$ & $\begin{array}{l}-0.002 \\
(0.004)\end{array}$ \\
\hline Observations & 6387 & 6387 & 2332 & 3412 & 3412 & 1233 \\
\hline R-squared & 0.39 & 0.46 & 0.41 & 0.35 & 0.52 & 0.48 \\
\hline Number of Districts & 162 & 162 & 17 & 162 & 162 & 17 \\
\hline $\begin{array}{l}\text { 4-Digit Industry-Year Interactions } \\
\text { "Treated" Control Group Used }\end{array}$ & & $\mathrm{X}$ & $\mathrm{X}$ & & $\mathrm{X}$ & $\mathrm{X}$ \\
\hline
\end{tabular}




\section{Table VII \\ Pre-Trend Falsification Tests}

This table reports coefficients from regressions using OLS with firm and year fixed effects. The dependent variable is the stock of bank loans normalized by 1991 assets in columns (1)-(4) and an indicator for FI loans in columns (5)-(8). Yearly observations from 1991 to 2002 are included for domestic, nonfinancial firms with positive sales and assets in 1991 but not located in a district with a foreign bank by 1991. 'Fake' is an indicator equal to 1 in the three years prior to foreign bank entry in the given district, and 'Foreign Bank' is equal to one for firms located in a district with a foreign bank in the given year, and zero otherwise. 'ROA' is a firm's 1991-1993 average percent return on assets, demeaned. Columns (3) \& (7) include 4-digit industry-year interactions. Columns (4) \& (8) restrict the sample to 'treated' firms located in districts with a foreign bank by 2004. Standard errors, clustered at the district-level, are reported in parentheses. $*=10 \%$ level, $* *=5 \%$ level, $* * *=1 \%$ level.

\begin{tabular}{|c|c|c|c|c|c|c|c|c|}
\hline \multirow[t]{2}{*}{ Dependent Variable = } & \multicolumn{4}{|c|}{ Bank Loans / 1991 Assets } & \multicolumn{4}{|c|}{ Indicator for FI Loan } \\
\hline & (5) & (6) & (7) & (8) & (1) & (2) & (3) & (4) \\
\hline Fake & $\begin{array}{l}-0.028 \\
(0.021)\end{array}$ & $\begin{array}{l}-0.026 \\
(0.019)\end{array}$ & $\begin{array}{l}-0.050 \\
(0.032)\end{array}$ & $\begin{array}{l}-0.034 \\
(0.038)\end{array}$ & $\begin{array}{l}-0.006 \\
(0.026)\end{array}$ & $\begin{array}{l}-0.004 \\
(0.025)\end{array}$ & $\begin{array}{l}-0.018 \\
(0.030)\end{array}$ & $\begin{array}{c}0.004 \\
(0.035)\end{array}$ \\
\hline Foreign Bank & $\begin{array}{c}0.023 \\
(0.060)\end{array}$ & $\begin{array}{c}0.012 \\
(0.054)\end{array}$ & $\begin{array}{l}-0.002 \\
(0.057)\end{array}$ & $\begin{array}{c}0.008 \\
(0.033)\end{array}$ & $\begin{array}{c}-0.088^{*} \\
(0.046)\end{array}$ & $\begin{array}{c}-0.090 * \\
(0.046)\end{array}$ & $\begin{array}{l}-0.077 \\
(0.052)\end{array}$ & $\begin{array}{l}-0.069 \\
(0.051)\end{array}$ \\
\hline Fake $*$ ROA & & $\begin{array}{l}-0.001 \\
(0.001)\end{array}$ & $\begin{array}{c}0.001 \\
(0.001)\end{array}$ & $\begin{array}{l}-0.000 \\
(0.002)\end{array}$ & & $\begin{array}{l}-0.001 \\
(0.003)\end{array}$ & $\begin{array}{l}-0.001 \\
(0.003)\end{array}$ & $\begin{array}{l}-0.001 \\
(0.003)\end{array}$ \\
\hline Foreign Bank * ROA & & $\begin{array}{c}0.005^{* *} \\
(0.003)\end{array}$ & $\begin{array}{c}0.008 * * \\
(0.003)\end{array}$ & $\begin{array}{c}0.006^{* * *} \\
(0.002)\end{array}$ & & $\begin{array}{l}-0.001 \\
(0.003)\end{array}$ & $\begin{array}{l}-0.000 \\
(0.003)\end{array}$ & $\begin{array}{l}-0.002 \\
(0.003)\end{array}$ \\
\hline Observations & 7088 & 7088 & 7088 & 2617 & 7088 & 7088 & 7088 & 2617 \\
\hline R-squared & 0.42 & 0.43 & 0.50 & 0.53 & 0.64 & 0.65 & 0.72 & 0.65 \\
\hline Number of Districts & 162 & 162 & 162 & 17 & 162 & 162 & 162 & 17 \\
\hline $\begin{array}{l}\text { ROA-Year Interactions } \\
\text { 4-Digit Industry-Year Interactions } \\
\text { "Treated" Control Group Used }\end{array}$ & & $\mathrm{X}$ & $\begin{array}{l}X \\
X\end{array}$ & $\mathrm{X}$ & & $\mathrm{X}$ & $\begin{array}{l}X \\
X\end{array}$ & $\mathrm{X}$ \\
\hline
\end{tabular}


Table VIII

\section{First Stage Regression}

This table reports coefficients from regressions using OLS with firm and year fixed effects. The dependent variable is 'Foreign Bank', which is equal to one for firms located in a district with a foreign bank in the given year, and zero otherwise. On the RHS, 'Foreign-Owned Firms in 1993', an indicator equal to one for firms located in districts with at least one foreign-owned firm in 1993, is interacted with a post-1993 year indicator Yearly observations from 1991 to 2002 are included for firms with positive sales and assets in 1991 but not located in a district with a foreign bank by 1991. Standard errors, clustered at the district-level, are reported in parentheses. $*=$ $10 \%$ level, $* *=5 \%$ level, $* * *=1 \%$ level.

\begin{tabular}{lc}
\hline & $\begin{array}{c}\text { Dependent Variable }= \\
\text { 'Foreign Bank' }\end{array}$ \\
\cline { 2 - 2 } Foreign-Owned Firms in 1993* Post-1993 & $0.341 * * *$ \\
& $(0.124)$ \\
Observations & 7088 \\
R-squared & 0.65 \\
\hline
\end{tabular}




\section{Table IX}

\section{Instrumental Variable Estimates of Foreign Bank Entry}

This table reports coefficients from regressions of various loan measures onto district and firm characteristics using instrumental variable estimates with firm and year fixed effects, and ROA-year interactions. 'Foreign Bank' is equal to one for firms located in a district with a foreign bank in the given year, and zero otherwise. 'ROA' is a firm's 1991-1993 average percent return on assets, demeaned. Instruments used are 'Foreign-Owned Firm in 1993'* post-1993 year dummy and 'Foreign-Owned Firm in 1993'* 'ROA'* post-1993 year dummy, where 'Foreign-Owned Firms in 1993', an indicator equal to 1 for firms located in districts with at least one foreign-owned firm in 1993. Yearly observations from 1991 to 2002 are included for domestic, non-financial firms with positive sales and assets in 1991 but not located in a district with a foreign bank by 1991. Standard errors, clustered at the districtlevel, are reported in parentheses. $*=10 \%$ level, $* *=5 \%$ level, $* * *=1 \%$ level.

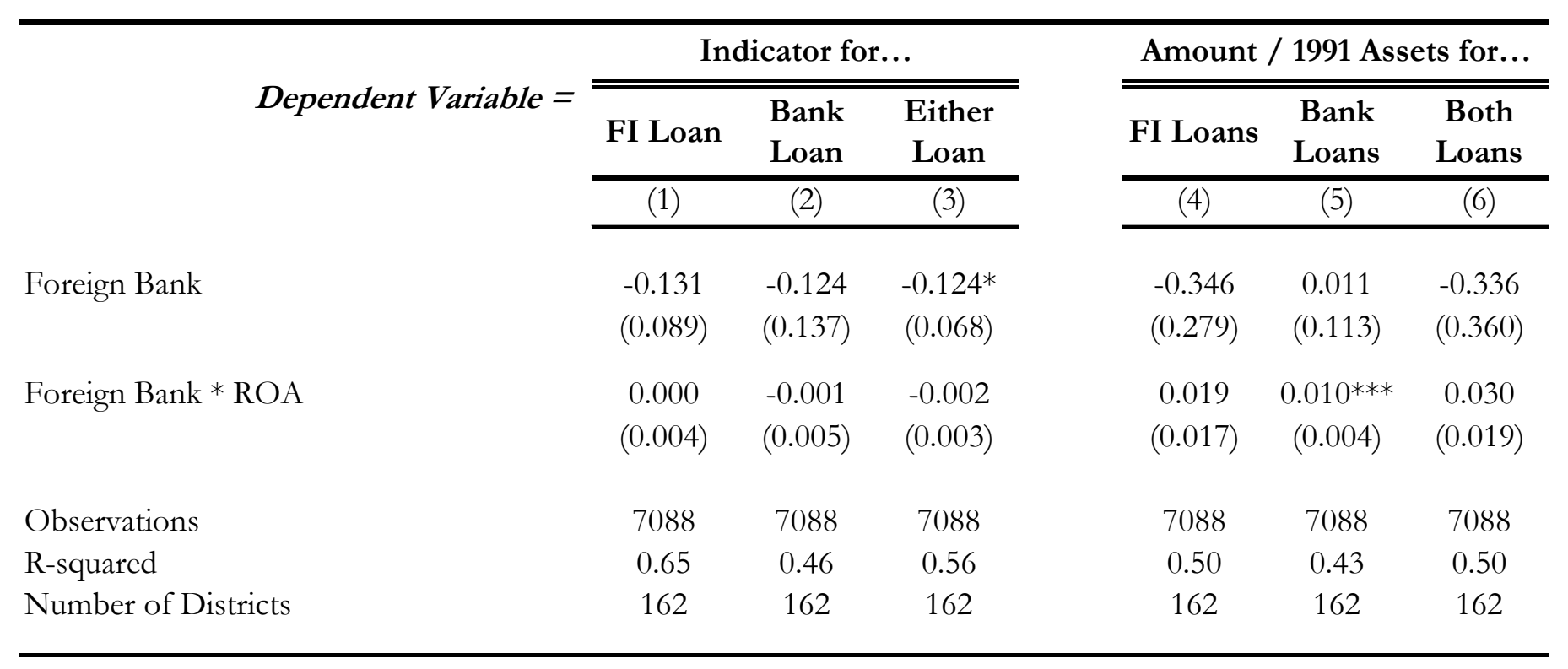


Table X

\section{Differential Impact of Foreign Entry on Credit Access}

This table reports coefficients from regressions of long-term loans / 1991 assets onto district and firm characteristics using ordinary least square estimates with firm and year fixed effects, and ROA-year interactions. 'Foreign Bank' is equal to one for firms located in a district with a foreign bank in the given year, and zero otherwise. 'ROA' is a firm's 1991-1993 average percent return on assets, demeaned. Yearly observations from 1991 to 2002 are included for domestic, non-financial firms with positive sales and assets in 1991 but not located in a district with a foreign bank by 1991. In columns (1)-(2), the sample is further restricted to firms with total assets in the bottom and top quartiles as of 1991. In columns (3)-(4), the sample is restricted to firms with 'tangibility' in the bottom and top quartiles as of 1991, where 'tangibility' is measured using Berger et al. (1996) and is equal to $\left(0.715^{*}\right.$ receivables +

$0.547 *$ inventory $+0.535 *$ fixed assets + cash $) /$ total assets. Standard errors, clustered at the district-level, are reported in parentheses. $*=10 \%$ level, $* *=5 \%$ level, $* * *=1 \%$ level.

\section{Dependent Variable = Long-term Loans $/ 1991$ Assets}

\begin{tabular}{|c|c|c|c|c|}
\hline & $\begin{array}{l}\text { Small } \\
\text { Firms }\end{array}$ & $\begin{array}{l}\text { Large } \\
\text { Firms }\end{array}$ & $\begin{array}{c}\text { Low } \\
\text { Tangibility }\end{array}$ & $\begin{array}{c}\text { High } \\
\text { Tangibility }\end{array}$ \\
\hline & (1) & (2) & (3) & (4) \\
\hline Foreign Bank & $\begin{array}{l}-0.537^{*} \\
(0.276)\end{array}$ & $\begin{array}{l}-0.072 \\
(0.052)\end{array}$ & $\begin{array}{c}-0.613^{* *} \\
(0.231)\end{array}$ & $\begin{array}{l}-0.041 \\
(0.049)\end{array}$ \\
\hline Foreign Bank * ROA & $\begin{array}{l}-0.022 \\
(0.160)\end{array}$ & $\begin{array}{l}-0.006^{*} \\
(0.003)\end{array}$ & $\begin{array}{c}-0.069 * * \\
(0.031)\end{array}$ & $\begin{array}{l}0.017^{*} \\
(0.010)\end{array}$ \\
\hline
\end{tabular}

ROA-Year Interactions

Observations

X X

R-squared

1669

$\mathrm{X}$

0.49

1863

Number of Districts

79

$\begin{array}{cc}\mathrm{X} & \mathrm{X} \\ 1737 & 1796 \\ 0.50 & 0.46 \\ 74 & 88\end{array}$




\section{Table XI}

\section{Access to Loans for Group versus Non-Group Firms}

This table reports coefficients from regressions of FI and bank loan indicators onto district and firm characteristics using OLS with firm and year fixed effects. Yearly observations from 1991 to 2002 are included for domestic, non-financial firms with positive sales and assets in 1991 but not located in a district with a foreign bank by 1991. The sample is restricted to 'Group' firms in columns (1)-(2) and 'NonGroup' firms in columns (3)-(4). 'Foreign Bank' is equal to one for firms located in a district with a foreign bank in the given year, and zero otherwise. 'ROA' is a firm's 1991-1993 average percent return on assets, demeaned. Standard errors, clustered at the district-level, are reported in parentheses. $*=10 \%$ level, $* *=5 \%$ level, $* * *=1 \%$ level.

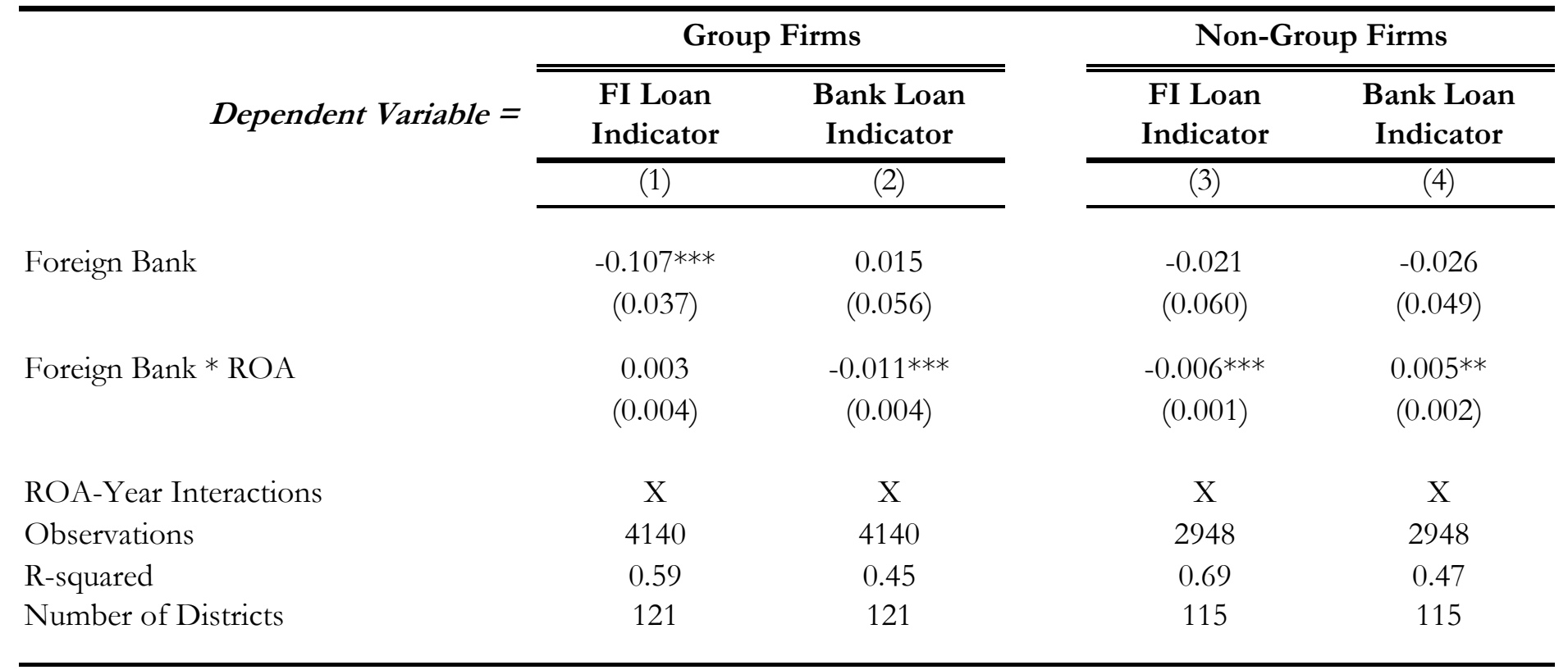




\section{Table XII}

\section{Effect of Foreign Bank Entry on Firm Performance}

This table reports coefficients from regressions of various firm measures onto district and firm characteristics using ordinary least square estimates with firm and year fixed effects, and RZ-year interactions. 'Foreign Bank' is equal to one for firms located in a district with a foreign bank in the given year, and zero otherwise. 'RZ' is the de-meaned 3-digit industry-level measure of external finance dependency provided by Rajan and Zingales (1998). ROA is the firms average percent return on assets and CAPEX is $\log$ (gross fixed assets). Yearly observations from 1991 to 2002 are included for domestic, non-financial firms with positive sales and assets in 1991 but not located in a district with a foreign bank by 1991. In Columns (1)-(4), the sample is restricted to firms with total assets in the bottom quartile as of 1991, and in columns (5)-(8), the sample is restricted to firms with total assets in the upper quartile as of 1991. Standard errors, clustered at the district-level, are reported in parentheses. $*=10 \%$ level, $* *=5 \%$ level, $* * *=1 \%$ level.

\begin{tabular}{|c|c|c|c|c|c|c|c|c|}
\hline \multirow{3}{*}{ Dependent Variable = } & \multicolumn{4}{|c|}{ Small Firms } & \multicolumn{4}{|c|}{ Large Firms } \\
\hline & Log(Sales) & ROA & $\begin{array}{l}\text { Cash / } \\
\text { Assets }\end{array}$ & CAPEX & Log(Sales) & ROA & $\begin{array}{l}\text { Cash / } \\
\text { Assets }\end{array}$ & CAPEX \\
\hline & (1) & (2) & (3) & (3) & $(5)$ & (6) & (7) & (8) \\
\hline Foreign Bank & $\begin{array}{c}0.009 \\
(0.174)\end{array}$ & $\begin{array}{c}0.029 \\
(0.112)\end{array}$ & $\begin{array}{l}-0.246 \\
(0.174)\end{array}$ & $\begin{array}{l}-0.064 \\
(0.129)\end{array}$ & $\begin{array}{c}0.108 \\
(0.142)\end{array}$ & $\begin{array}{c}0.026 \\
(0.020)\end{array}$ & $\begin{array}{l}-0.006 \\
(0.008)\end{array}$ & $\begin{array}{c}0.071 \\
(0.076)\end{array}$ \\
\hline Foreign Bank * RZ Index & $\begin{array}{c}-0.602 * * \\
(0.247)\end{array}$ & $\begin{array}{c}-0.701 * * \\
(0.311)\end{array}$ & $\begin{array}{c}-1.143^{*} \\
(0.612)\end{array}$ & $\begin{array}{c}-0.809 * * * \\
(0.003)\end{array}$ & $\begin{array}{c}0.328 \\
(0.330)\end{array}$ & $\begin{array}{l}0.154 * \\
(0.080)\end{array}$ & $\begin{array}{l}-0.003 \\
(0.017)\end{array}$ & $\begin{array}{c}0.226 \\
(0.261)\end{array}$ \\
\hline RZ-Year Interactions & $\mathrm{X}$ & $\mathrm{X}$ & $\mathrm{X}$ & $\mathrm{X}$ & $\mathrm{X}$ & $\mathrm{X}$ & $\mathrm{X}$ & $\mathrm{X}$ \\
\hline Observations & 1591 & 1611 & 1611 & 1611 & 1687 & 1694 & 1694 & 1694 \\
\hline R-squared & 0.80 & 0.39 & 0.34 & 0.80 & 0.79 & 0.66 & 0.51 & 0.92 \\
\hline Number of Districts & 77 & 77 & 77 & 77 & 73 & 73 & 73 & 73 \\
\hline
\end{tabular}


Appendix Table I

Firm Observations Dropped by Year

\begin{tabular}{|c|c|c|c|c|c|c|c|c|c|c|c|c|}
\hline & 1991 & 1992 & 1993 & 1994 & 1995 & 1996 & 1997 & 1998 & 1999 & 2000 & 2001 & 2002 \\
\hline Total Number of Firms in Prowess Data & 2068 & 2415 & 3013 & 4004 & 5144 & 5607 & 5720 & 5658 & 5984 & 6385 & 5559 & 3571 \\
\hline \multicolumn{13}{|l|}{ Observations Dropped } \\
\hline Missing District Location & 13 & 21 & 42 & 71 & 106 & 127 & 131 & 126 & 146 & 163 & 119 & 50 \\
\hline No Sales or Assets in 1991 & 61 & 458 & 1085 & 2021 & 3135 & 3589 & 3723 & 3697 & 4006 & 4369 & 3748 & 2249 \\
\hline Foreign-Owned Firms & 202 & 198 & 199 & 194 & 192 & 189 & 192 & 198 & 199 & 200 & 188 & 118 \\
\hline Financial or Banking Firms & 89 & 86 & 82 & 86 & 83 & 85 & 85 & 84 & 81 & 81 & 72 & 58 \\
\hline In District with Foreign Bank in 1991 & 1047 & 1015 & 992 & 1000 & 994 & 984 & 970 & 959 & 969 & 993 & 922 & 698 \\
\hline Number of Firms in Regressions & 656 & 637 & 613 & 632 & 634 & 633 & 619 & 594 & 583 & 579 & 510 & 398 \\
\hline
\end{tabular}

